\title{
Caracterização qualitativa e quantitativa dos grupos bacterianos responsáveis pelos processos de oxidação e redução de nitrogênio em sistemas de tratamento de águas residuárias
}

\author{
Characterization qualitative and quantitative of groups bacterial responsible for the processes \\ oxidation and reduction of nitrogen in systems treatment wastewater \\ Caracterización cualitativa y cuantitativa de los grupos bacterianos responsables de los procesos de \\ oxidación y reducción de nitrógeno en los sistemas de tratamiento de aguas residuales
}

Recebido: 13/01/2021 | Revisado: 15/01/2021 | Aceito: 22/01/2021 | Publicado: 30/01/2021

\author{
Jefferson Santos de Amorim \\ ORCID: https://orcid.org/0000-0002-5630-7373 \\ Universidade Estadual da Paraíba, Brasil \\ E-mail: bio_jefferson20@hotmail.com \\ Gabriely Dias Dantas \\ ORCID: https://orcid.org/0000-0002-8684-7581 \\ Universidade Estadual da Paraíba, Brasil \\ E-mail: gabrielydias4@gmail.com \\ Valderi Duarte Leite \\ ORCID: https://orcid.org/0000-0001-5861-7407 \\ Universidade Estadual da Paraíba, Brasil \\ E-mail: mangabeiraleite@gmail.com \\ Beatriz Susana Ovruski de Ceballos \\ ORCID: https://orcid.org/0000-0003-0458-4667 \\ Universidade Estadual da Paraíba, Brasil \\ E-mail: bia.ceballos@gmail.com \\ André Luiz Queiroga Reis \\ ORCID: https://orcid.org/0000-0003-2736-2995 \\ Universidade federal da Paraíba, Brasil \\ E-mail: andre_queiroga@yahoo.com.br
}

\begin{abstract}
Resumo
Neste trabalho objetivou-se realizar a caracterização qualitativa e quantitativa dos grupos bacterianos responsáveis pelos processos de oxidação e redução de nitrogênio, aplicando-se a técnica do número mais provável (NMP) em um sistema experimental constituído por reator UASB, Filtro Biológico Percolador (FBP) e reator anóxico, instalados e monitorados de forma sequenciada no processo de tratamento de lixiviado de aterro sanitário e esgoto doméstico. A eficiência da etapa de amonificação constatada durante a etapa de conversão do nitrogênio orgânico a inorgânico, no reator UASB foi de $6,4 \%$, representando um acréscimo de $9,8 \mathrm{mg} / \mathrm{L}$ de nitrogênio amoniacal no efluente do reator. O NMP das bactérias oxidantes de amônia (BOA) variou de $0,8 \times 10^{2}$ a $1,4 \times 10^{5} \mathrm{NMP} / 100 \mathrm{ml}$. Já o NMP das Oxidantes de nitrito

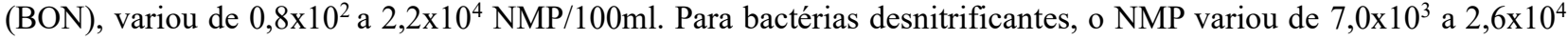
$\mathrm{NMP} / 100 \mathrm{ml}$. A remoção biológica de nitrogênio amoniacal observada no FBP, apresentou eficiência média de $16,42 \%$, gerando um efluente com concentração média de $136,4 \mathrm{mg} \mathrm{N}-\mathrm{NH}_{4}{ }^{+} \cdot \mathrm{L}^{-1}$ no FBP. Com base nesses resultados, o sistema experimental demonstrou capacidade de realizar os processos globais de transformação do nitrogênio. Porém, destacase a necessidade do controle rigoroso nos parâmetros operacionais, para atingir maiores eficiências na remoção no nitrogênio a longo prazo.
\end{abstract}

Palavras-chave: Lixiviado de aterro sanitário; Esgoto doméstico; Nitrificação e desnitrificação.

\begin{abstract}
This work was aimed at to perform the characterization qualitative and quantitative of the bacterial groups responsible for the oxidation and nitrogen reduction processes, applying the most likely number (NMP) technique in an experimental system consisting of UASB reactor, Percolator Biological Filter (FBP) and anoxic reactor, installed and monitored sequentially in the process of leachate treatment from landfill and domestic sewage. The efficiency of the ammonification stage observed during the conversion phase from organic to inorganic nitrogen in the UASB reactor was $6.4 \%$, representing an increase of $9.8 \mathrm{mg} / \mathrm{L}$ of ammoniacal nitrogen in the effluent of the reactor. The NMP of ammonia oxidizing bacteria (AOB) ranged from $0,8 \times 10^{2}$ a $1,4 \times 10^{5} \mathrm{NMP} / 100 \mathrm{ml}$. The NMP of nitrite oxidizers (NOB), varied from $0,8 \times 10^{2}$ a $2,2 \times 10^{4} \mathrm{NMP} / 100 \mathrm{ml}$. For denitrifying bacteria, the NMP ranged from $7,0 \times 10^{3}$ a $2,6 \times 10^{4}$
\end{abstract}


NMP/100ml. The removal biological nitrogen ammoniacal observed in the FBP showed an average efficiency of $16.42 \%$, generating an effluent with an average concentration of $136.4 \mathrm{mg} \mathrm{NH}_{4}^{+}$. $\mathrm{L}^{-1}$ in the FBP. Based on these results, the system experimental demonstrated the ability to carry out global nitrogen transformation processes. However, the need for strict control over operational parameters is highlighted, in order to achieve greater efficiencies in nitrogen removal in the long run.

Keywords: Landfill leachate; Domestic sewage; Nitrification and denitrification.

\section{Resumen}

En este trabajo se objetivó realizar la caracterización cualitativa y cuantitativa de los grupos bacterianos responsables de los procesos de oxidación y reducción de nitrógeno, aplicando la técnica del número más probable (NMP) en un sistema experimental compuesto por reactor UASB, Filtro Biológico Percolador (FBP) y reactor anóxico, instalado y monitoreado secuencialmente en el proceso de tratamiento de lixiviados de relleno sanitario y alcantarillado doméstico. La eficiencia de la etapa de amonificación observada durante la fase de conversión de nitrógeno orgánico a inorgánico en el reactor UASB fue del 6,4\%, lo que representa un incremento de 9,8 $\mathrm{mg} / \mathrm{L}$ de nitrógeno amoniacal en el efluente del reactor. La NMP de las bacterias oxidantes de amoniaco (BOA) osciló entre $0,8 \times 10^{2}$ y $1,4 \times 10^{5} \mathrm{NMP} / 100 \mathrm{ml}$. La NMP de los oxidantes de nitrito (BON), varió de $0,8 \times 10^{2}$ a 2,2×104 NMP/100ml. Para las bacterias desnitrificantes, el NMP varió de $7,0 \times 10^{3}$ a 2,6×10 $\mathrm{NMP} / 100 \mathrm{ml}$. La remoción biológica de nitrógeno amoniacal observada en el FBP mostró una eficiencia promedio de 16,42\%, generando un efluente con una concentración promedio de $136,4 \mathrm{mg}$ $\mathrm{NH}_{4}{ }^{+} \cdot \mathrm{L}^{-1}$ en el FBP. Con base en estos resultados, el sistema experimental demostró la capacidad de llevar a cabo procesos globales de transformación de nitrógeno. Sin embargo, se destaca la necesidad de un control estricto de los parámetros operativos, con el fin de lograr mayores eficiencias en la remoción de nitrógeno a largo plazo.

Palabras clave: Lixiviados de vertederos; Alcantarillado doméstico; Nitrificación y desnitrificación.

\section{Introdução}

A cultura do consumismo em consonância com o crescimento populacional observado desde o período pós revolução industrial, vem contribuindo significativamente para a degradação dos recursos naturais ao longo dos anos. Todo processo de produção e de consumo, gera resíduos que exemplifica uma das atividades que tem potencial para provocar mudanças das características físicas, químicas e biológicas, sobretudo dos sistemas aquáticos.

A disposição inadequada de resíduos sólidos, representa um problema de má gestão dos municípios na maioria dos países subdesenvolvidos e em desenvolvimento. Segundo dados do Sistema Nacional de Informações sobre Saneamento (SNIS), no ano de 2018, no Brasil o percentual médio de tratamento de esgotos era 46,3\%, que representava um quantitativo de 4,30 bilhões de $\mathrm{m}^{3}$ de todo esgoto gerado nesse ano. Leite et al., (2021), afirmam que em relação ao sistema de esgotamento sanitário apresentado no país, o princípio da universalização do acesso não é alcançado para 50,7\% dos domicílios, indicando desta forma, que pouco mais da metade da população esteja passível de riscos inerentes a ausência ou deficiência de saneamento básico.

Esses dados remetem a um cenário de preocupação no âmbito ambiental no que tange a proteção dos corpos aquáticos. O esgoto bruto, apresenta em sua composição elevada concentração de matéria orgânica, compostos nitrogenados e fósforo, que podem desencadear sérios desequilíbrios ecossistêmicos quando despejados nos corpos d'águas sem tratamento.

A decomposição física, química e biológica dos Resíduos Sólidos Urbanos (RSU) seja em lixões, aterros sanitários ou a céu aberto, produz um efluente altamente poluidor com composição química variável e complexa, denominado de lixiviado, percolado ou chorume (Suzuki et al., 2013). Esse efluente apresenta elevada concentração de nitrogênio amoniacal, compostos tóxicos, metais pesados, elevada Demanda Química de Oxigênio (DQO) e Demanda Bioquímica de Oxigênio (DBO) (Christensen et al., 2001). Devido à importância ambiental desse efluente, diversas configurações de tratamento e tecnologias sustentáveis foram desenvolvidas nos últimos anos com a finalidade de atender os padrões de lançamento propostos pela legislação vigente.

A crescente demanda por água observada no século atual, remete a um cenário de proteção dos corpos aquáticos no que tange a mitigação dos impactos ocasionados aos recursos hídricos, em consequência da descarga de efluentes nos corpos receptores sem tratamento. A crescente exigência por novos processos de tratamento, caracteriza-se pela composição destes 
efluentes apresentarem grandes aportes de matéria orgânica e elevadas concentrações de macronutrientes como o nitrogênio e fósforo, que são os principais responsáveis pela eutrofização dos corpos aquáticos.

Os principais processos empregados para tratamento de efluentes são os processos físicos, químicos e biológicos. Porém, a combinação desses processos, proporcionam maiores eficiências de tratamento. Devido a elevada concentração de nitrogênio amoniacal presente no lixiviado de aterro sanitário, o tratamento conjugado deste efluente com esgoto doméstico, se apresenta como alternativa eficiente para obtenção de um efluente passivo de tratamento biológico.

Os processos biológicos empregados para remoção de compostos nitrogenados presentes em efluentes, ocorrem a partir das etapas de nitrificação e desnitrificação. A transformação da amônia em suas formas mais oxidadas nitrito e nitrato, é um processo biológico governado por diversos microrganismos, e é definida como nitrificação. O termo é utilizado para descrever o processo biológico que ocorre em duas etapas, onde um grupo de bactérias autotróficas oxidam a amônia a nitrito $\left(\mathrm{N}^{-\mathrm{NO}_{2}}{ }^{-}\right) \mathrm{e}$, um segundo grupo de bactérias autotróficas oxidam nitrito a nitrato $\left(\mathrm{N}^{-\mathrm{NO}_{3}}{ }^{-}\right)$(Metcalf \& Eddy, 2016).

A desnitrificação biológica é uma etapa do ciclo do nitrogênio, utilizada nos processos convencionais de remoção do nitrogênio em águas residuárias. Nesse processo, ocorre a redução do nitrato a nitrogênio gasoso $\left(\mathrm{N}_{2}\right)$, sob condições anóxicas. Na redução do nitrato a nitrogênio molecular, ocorre à transferência de cinco elétrons por átomo de nitrogênio, dos oito elétrons liberados pelo nitrogênio amoniacal na sua oxidação para nitrato, apenas cinco são recuperados quando o nitrato é reduzido para nitrogênio molecular (Zoppas et al., 2016).

O uso do reator anaeróbio de fluxo ascendente com manta de lodo (UASB) se apresenta como uma técnica apropriada para o tratamento secundário de esgotos, uma vez que esse reator remove $\mathrm{DQO}$ e $\mathrm{DBO}_{5}$ com eficiências superiores a 60 ou $70 \%$. (Souza et al., 2005). Porém, esse reator é considerado ineficiente na remoção de nutrientes, necessitando de sua associação com outras configurações de reatores para remover esses compostos.

A remoção biológica do nitrogênio presente em efluentes líquidos, torna-se possível através de uma série de reatores, sejam sistemas constituídos por reatores em série ou não, propiciando os processos de nitrificação e desnitrificação (Fleck et al., 2015).

O tratamento conjugado de lixiviado de aterro sanitário mais esgoto doméstico vem sendo realizado na Estação Experimental de Tratamentos Biológicos de Águas e Esgotos Sanitários - EXTRABES, vinculada a Universidade Estadual da Paraíba (UEPB). Esses sistemas, permitem a remoção nitrogênio em duas etapas: uma aeróbia (p. ex., filtro biológico percolador), seguido por uma etapa anaeróbia (p. ex., reator anóxico), para tratamento do efluente advindo do reator UASB, sendo visto como uma alternativa eficiente para tratamento desse tipo de efluente.

O objetivo deste trabalho foi avaliar a eficiência dos grupos bacterianos responsáveis pelos processos de remoção de nitrogênio em um sistema experimental composto por reator UASB (Reator Anaeróbio de Fluxo Ascendente), Filtro Biológico Percolador e Reator Anóxico, dispostos em série, no tratamento biológico do conjugado de lixiviado de aterro sanitário e esgoto doméstico, além de estimar as densidades populacionais bacterianas nitrificantes e desnitrificantes, através da técnica Número Mais Provável (NMP).

\section{Metodologia}

A metodologia utilizada nesse estudo, possui caráter quali-quantitativo. De acordo com Pereira et al., (2018), os métodos qualitativos são aqueles nos quais é importante a interpretação por parte do pesquisador com suas opiniões sobre o fenômeno em estudo. Já os métodos quantitativos, faz-se a coleta de dados quantitativos ou numéricos por meio do uso de medições de grandezas e obtém-se por meio da metrologia, números com suas respectivas unidades. Estes métodos geram uma infinidade de dados que podem ser analisados através de técnicas matemáticas como é o caso das porcentagens, estatísticas e probabilidades, métodos numéricos, métodos analíticos e geração de equações e/ou fórmulas matemáticas aplicáveis a algum processo. 
Deste modo, o estudo foi realizado na Estação Experimental de Tratamentos Biológicos de Esgotos Sanitários (EXTRABES), pertencente à Universidade Estadual da Paraíba (UEPB), com localização no Bairro do Tambor na Cidade de Campina Grande, PB, Brasil.

O lixiviado de aterro sanitário (LAS) utilizado para preparação do substrato, foi coletado no aterro sanitário localizado no engenho Mussuré, no distrito industrial, situado na região metropolitana de João Pessoa, PB. O esgoto doméstico utilizado na pesquisa foi proveniente do sistema de esgotamento sanitário da cidade de Campina Grande, PB, coletado no emissário leste e aduzido para um reservatório de polietileno, onde foi armazenado até o momento de preparação do substrato.

Para o preparo do substrato utilizado na alimentação do reator UASB, adotou-se a mistura de 3\% de lixiviado de aterro sanitário mais 97\% de esgoto doméstico (percentagem em volume). Essa proporção do volume de lixiviado utilizado, foi definida a partir da vazão obtida do lixiviado gerado no aterro sanitário, juntamente a vazão do esgoto doméstico gerado pela população da cidade de Campina Grande, durante o período experimental. Essa mistura forneceu a concentração inicial média de nitrogênio amoniacal de $150 \mathrm{mg} . \mathrm{L}^{-1}$. O processo de mistura era realizado diariamente, a cada evento de alimentação dos reatores. $\mathrm{O}$ sistema experimental é formado por um reator anaeróbio de fluxo ascendente com manta de lodo (UASB), seguido de filtro biológico percolador (FBP) e um reator anóxico dispostos sequencialmente.

O reator UASB foi construído em tubo de PVC rígido, com capacidade volumétrica de 42 litros, e cerca de 2,37 m de altura com diâmetro de $150 \mathrm{~mm}$. A carga orgânica volumétrica aplicada (COV) foi de $2,7 \mathrm{kgDQO} / \mathrm{m}^{3}$.dia, carga hidráulica volumétrica de $3 \mathrm{~m}^{3} \cdot \mathrm{m}^{-3} \cdot \mathrm{d}^{-1}$ e tempo de detenção hidráulica (TDH) de 8 horas. O substrato utilizado na alimentação do reator UASB, era direcionado por gravidade da base do reator, e seguia por fluxo ascendente até o topo do reator, onde o efluente era descarregado para alimentar o FBP.

O Filtro Biológico Percolador foi construído em tubo de PVC, com volume total de $35 \mathrm{~L}$, sendo 17 L preenchidos por meio de suporte brita $\mathrm{n}^{\circ} 4$, representando o índice de espaços vazios de 49\%. Possui altura de 1,80m, carga orgânica volumétrica aplicada de $1,2 \mathrm{kgDQO} / \mathrm{m}^{3}$.dia, carga hidráulica volumétrica de $4,0 \mathrm{~m}^{3} / \mathrm{m}^{3}$.dia, taxa de aplicação superficial de $2,7 \mathrm{~m}^{3} / \mathrm{m}^{2}$.dia e vazão do afluente de $48 \mathrm{~L} \cdot \mathrm{d}^{-1}$.

O filtro biológico percolador é alimentado em fluxo intermitente e o tempo de duração de cada ciclo é de 06 horas, totalizando quatro ciclos diários. Os ciclos são divididos nas fases de alimentação, descarga e repouso. O tempo de alimentação do FBP, coincide diretamente com tempo em que o efluente do reator UASB era bombeado para o filtro, consequentemente, a etapa de alimentação do FBP ocorria durante o período de 40 minutos. Após esta etapa, o efluente do FBP era descarregado por 20 minutos até que fosse totalmente esvaziado, e, em seguida, permanecendo em repouso por 5 horas.

A alimentação do reator anóxico ocorreu após o efluente do FBP ser bombeado forma descendente para o reator anóxico.

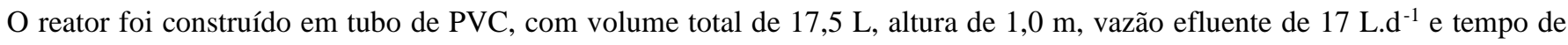
detenção hidráulica de 24 horas.

\subsection{Coleta das Amostras - Monitoração}

Com a finalidade de realizar o uso da técnica de quantificação NMP de bactérias nitrificantes e desnitrificantes, presentes no sistema de tratamento de águas residuárias durante o monitoramento do sistema experimental, foram realizadas 5 coletas de amostras dos efluentes oriundos do Filtro Biológico Percolador e Reator Anóxico. O sistema é separado por escala temporal, onde o tratamento do efluente segue em fase aeróbia seguida por fase anóxica. Essa configuração de reatores, pode ser significativa no entendimento sobre a dinâmica dos processos de nitrificação e desnitrificação nesses sistemas.

O volume do efluente coletado para realização do teste quantitativo NMP, foi de $1000 \mathrm{ml}$ no FBP e $1000 \mathrm{ml}$ no reator anóxico, a cada coleta realizada. Essas amostras foram coletadas e armazenadas em frascos plásticos (esterilizados em autoclave por 20 minutos a $120^{\circ} \mathrm{C}$ ) hermeticamente fechados. O período de coleta ocorreu durante os meses de agosto de 2020 a dezembro 
de 2020. Na Figura 1 apresenta-se o desenho esquemático do sistema experimental utilizado no presente estudo.

Figura 1.Reatores utilizados no experimento. (1) Reator UASB; (2) Filtro Biológico Percolador; (3) Reator Anóxico.

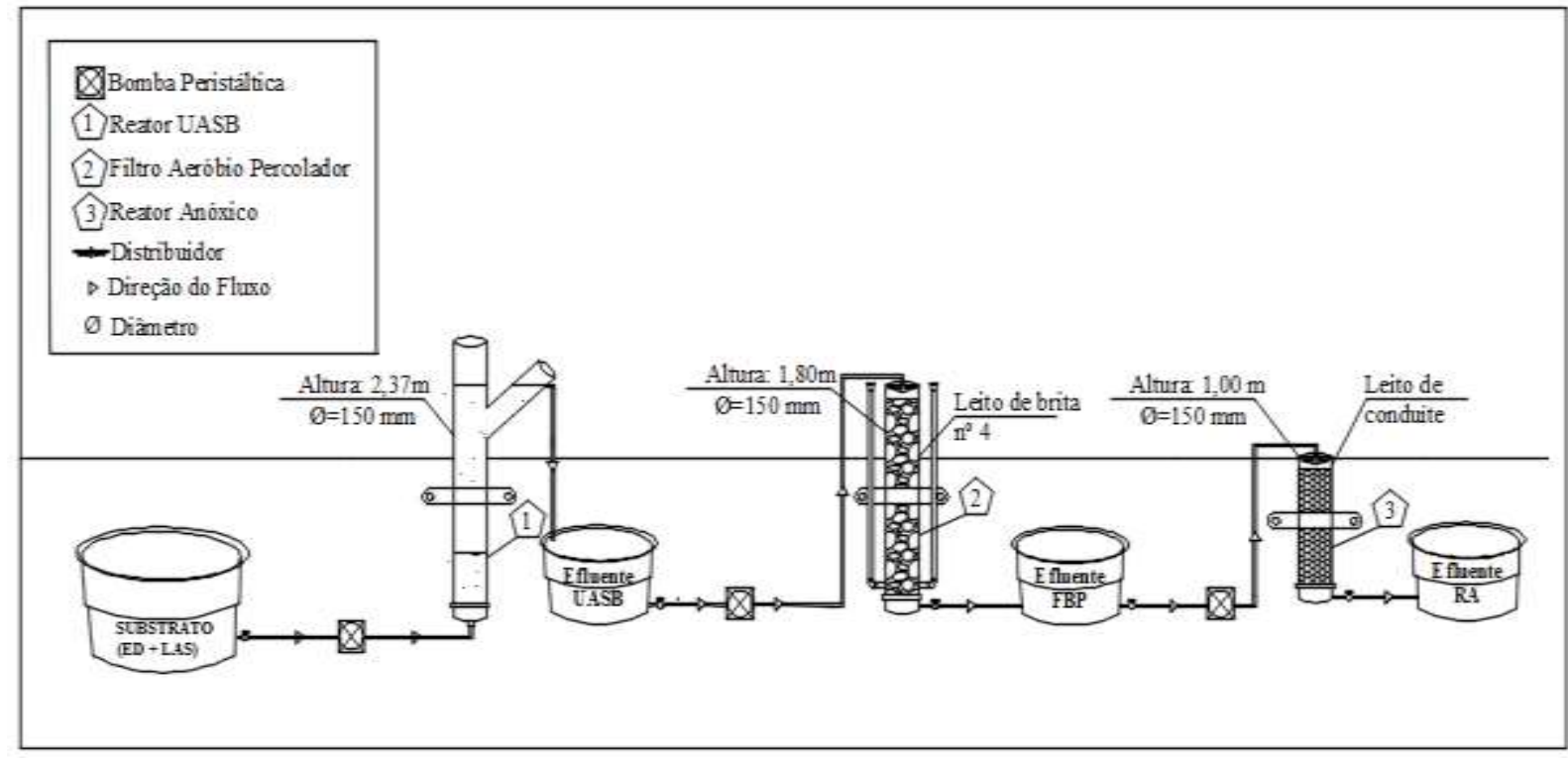

Fonte: Autores.

\subsection{Quantificação de Bactérias Nitrificantes e Desnitrificantes - Número Mais Provável (NMP)}

Nesta pesquisa, a técnica de diluições seriadas decimais utilizadas para quantificar as bactérias nitrificantes, foi seguida de acordo com o método utilizado por Mendonça (2002). Para realização da etapa de diluição das amostras, adicionou-se $2 \mathrm{ml}$ da solução de $\mathrm{K}_{2} \mathrm{HPO}_{4}$ e $0,5 \mathrm{ml}$ da solução de $\mathrm{KH}_{2} \mathrm{PO}_{4}$, completando o volume para $500 \mathrm{ml}$ com água Milli-Q. Em seguida, adicionou-se $2 \mathrm{~mL}$ da amostra ao tubo contendo $18 \mathrm{~mL}$ da água de diluição, obtendo a diluição $10^{-1}$. Após a homogeneização do tubo contendo a diluição $10^{-1}$, retirou $2 \mathrm{~mL}$, e adicionou-se a outro tubo contendo a água de diluição, obtendo a diluição $10^{-2}$, seguindo esta etapa até obter a diluição $10^{-8}$.

Para o preparo do meio de cultura seletivo utilizado para quantificação das bactérias nitrificantes (oxidantes de amônia e oxidantes de nitrito), utilizou-se os critérios utilizados na metodologia descrita por Mendonça (2002), adicionando-se os seguintes compostos químicos: meio para oxidantes de amônia (5,00 g de $\left(\mathrm{NH}_{4}\right) 2 \mathrm{SO}_{4} ; 0,85 \mathrm{~g}$ de $\mathrm{KNO}_{2} ; 1,34 \mathrm{~g} \mathrm{de} \mathrm{CaCl}_{2} .2 \mathrm{H}_{2} \mathrm{O}$; 4,00 $\mathrm{g}$ de $\mathrm{MgSO}_{4}$. 7 $\mathrm{H}_{2} \mathrm{O}$; 0,04 $\mathrm{g}$ de azul de bromotimol; 2,72 $\mathrm{g}$ de $\mathrm{KH}_{2} \mathrm{PO}_{4}(0,2 \mathrm{M}) ; 0,331 \mathrm{~g}$ de EDTA.2NA; 0,246 $\mathrm{g}$ de $\mathrm{FeSO}_{4} .2 \mathrm{H}_{2} \mathrm{O} ; 0,0422 \mathrm{~g}$ de Elementos traço, em $500 \mathrm{ml}$ de água Milli-Q). Para oxidantes de nitrito $\left(0,69 \mathrm{~g}\right.$ de $\mathrm{NaNO}_{2} ; 1,34 \mathrm{~g}$ de $\mathrm{CaCl}_{2} .2 \mathrm{H}_{2} \mathrm{O} ; 4,00 \mathrm{~g}$ de $\mathrm{MgSO}_{4} .7 \mathrm{H}_{2} \mathrm{O} ; 3,48 \mathrm{~g}$ de $\mathrm{K}_{2} \mathrm{HPO}_{4}(0,2 \mathrm{M}) ; 2,72 \mathrm{~g}$ de $\mathrm{KH}_{2} \mathrm{PO}_{4}(0,2 \mathrm{M}) ; 0,331 \mathrm{~g}$ de EDTA.2NA; 0,246 g de $\mathrm{FeSO}_{4} .2 \mathrm{H}_{2} \mathrm{O} ; 0,0422 \mathrm{~g}$ de Elementos traço, em $500 \mathrm{ml}$ de água Milli-Q).

Para o preparo do meio de cultura para bactérias desnitrificantes, foi utilizado os critérios utilizados na metodologia seguida por Mendonça (2002). Foi dissolvido em um becker, $2 \mathrm{~g}$ do caldo nutriente (Nutrient Broth - Acumedia) em pó, e, em seguida adicionou-se $0,107 \mathrm{~g}$ de $\mathrm{NaNO}_{3}$, e ambos foram introduzidos em balão e o volume completado para $250 \mathrm{~mL}$, com água Milli-Q.

Para bactérias nitrificantes e desnitrificantes, utilizou-se 5 tubos para cada diluição das amostras. As amostras foram incubadas de acordo com o tempo de crescimento de cada grupo bacteriano, que são de 30 dias para as bactérias nitrificantes (BOA e BON) e cerca de 15 dias para as bactérias desnitrificantes. Os resultados obtidos do NMP dos microrganismos, representam um índice de confiança de $95 \%$, tendo em vista que o método não determina a concentração exata e sim o número mais provável. A estimativa do NMP é realizada com base na combinação dos resultados dos tubos positivos, conforme a 
Equação 1, utilizando a tabela padrão de probabilidade (Apha, 2012).

$$
\mathrm{NMP} / 100 \mathrm{ml}=\frac{\text { valor do NMP }(\text { tabela }) \times 10}{\text { maior diluição da combinação de tubos positivos }}
$$

Onde:

NMP: número mais provável

De acordo com Ceballos e Diniz (2017), essa técnica foi inicialmente desenvolvida para quantificar pelo menos um coliforme em $100 \mathrm{~mL}$. Posteriormente essa técnica foi adaptada para águas residuárias, onde inoculam-se alíquotas menores da amostra (diluições decimais da amostra original: 1/10, 1/100, 1/1000, 1/10.000 1/100.000, etc.) em tubos individuais, podendo haver repetições de três a cinco vezes com meio de cultura em quantidades e concentrações apropriadas.

Após o período de incubação, adicionou-se três soluções testes responsáveis pela leitura do consumo do nitrito e do nitrato. Para bactérias desnitrificantes, a solução (a), continha 0,2g de difenilamina $\left.\left[\left(\mathrm{C}_{6} \mathrm{H}_{5}\right)_{2} \mathrm{NH}\right)\right]$ diluída em $100 \mathrm{~mL}$ de ácido sulfúrico $\left(\mathrm{H}_{2} \mathrm{SO}_{4}\right)$. Solução (b), continha $0,5 \mathrm{~g}$ de sulfanilamida em $100 \mathrm{~mL}$ de ácido clorídrico $(\mathrm{HCl})$ 2,4N. Solução (c), dissolveu-se 0,3g de N-naftil-etilenodiamina hidrocloreto em $100 \mathrm{~mL}$ de ácido clorídrico $(\mathrm{HCl})$ 0,12N. Todos os reagentes foram armazenados em ambiente livre de luminosidade e sob refrigeração.

Na Figura 2, apresenta-se o fluxograma das etapas de diluição das amostras e inoculação em meio de cultura seletivo para bactérias nitrificantes e desnitrificantes.

Figura 2. Fluxograma das análises microbiológicas.

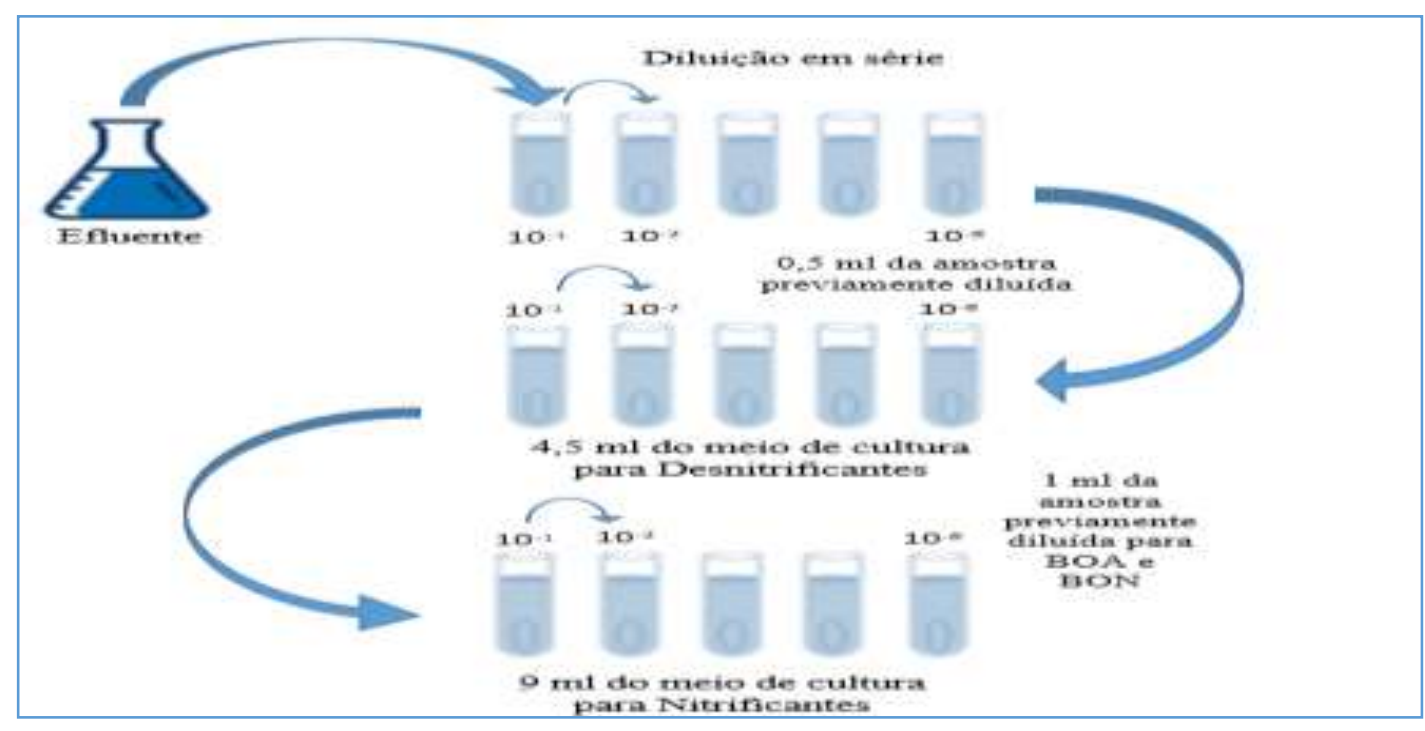

Fonte: Autores.

\subsection{Análises dos Parâmetros Físico-químicas}

As análises físico-químicas foram realizadas na Estação Experimental de Tratamentos Biológicos de Esgotos Sanitários (EXTRABES), pertencente à Universidade Estadual da Paraíba (UEPB). As análises químicas do substrato e dos efluentes dos reatores, seguiram as normas estabelecidas pelo Standard Methods for the Examination of Water and Wastewater (Apha, 2012). Deste modo, durante o monitoramento do sistema experimental, foram avaliados os seguintes parâmetros: $\mathrm{pH}$, alcalinidade total, nitrogênio amoniacal $\left(\mathrm{N}-\mathrm{NH}_{4}{ }^{+}\right)$, nitrito $\left(\mathrm{N}-\mathrm{NO}_{2}^{-}\right)$e nitrato $\left(\mathrm{N}^{-} \mathrm{NO}_{3}^{-}\right)$. 


\section{Resultados e Discussão}

\subsection{Potencial Hidrogeniônico - (pH)}

$\mathrm{O}$ pH é um dos parâmetros preponderantes em sistemas de tratamento, pois interferem diretamente no metabolismo bacteriano. Na etapa de digestão anaeróbia, a manutenção do equilíbrio do $\mathrm{pH}$ em faixas próximas a neutralidade, garante maior eficiência das archeas metanogênicas na estabilização da matéria orgânica, tendo como produto desse metabolismo, a formação do gás metano $\left(\mathrm{CH}_{4}\right)$.

Para a grande maioria das bactérias, o pH ótimo de crescimento situa-se na faixa entre 6,5 e 7,5, e suas respectivas variações máximas e mínimas, para a maior parte delas, estão a baixo de pH 4 e acima de 9 (Pereira et al., 2009). A oscilação dos valores de pH na etapa de digestão anaeróbia, está diretamente relacionada com a produção de ácidos voláteis durante a transformação da matéria orgânica.

O substrato utilizado na alimentação do sistema experimental, apresentou variação de $\mathrm{pH}$ entre 7,4 e 7,6, sendo representado pelo valor médio de 7,5. Diante da complexidade do substrato, observa-se que esse valor não apresenta interferência significativa nos processos metabólicos subsequentes a inoculação no reator UASB. A Figura 3, apresenta a variação temporal do $\mathrm{pH}$ no substrato e nos efluentes dos reatores UASB, FBP e reator anóxico, durante o monitoramento do sistema experimental.

No reator UASB, observou-se durante o experimento, variações na faixa de pH entre 7,6 e 7,7. Deste modo, o comportamento do pH no reator UASB, não representou impacto significativo na dinâmica dos microrganismos metanogênicos decompositores, que em decorrência desse processo de degradação da matéria orgânica, produzem alcalinidade e amônia. Pereira et al., (2009), afirmam que quando os valores de pH em um sistema de tratamento anaeróbio está entre 6,7 e 8,0, a concentração de ácidos orgânicos está em sua maioria (>99\%) em sua forma ionizada (não tóxica), não interferindo no metabolismo dasbactérias metanogênicas.

Figura 3.Comportamento da variação temporal do pH do substrato e dos efluentes do reator UASB, FBP e Reator Anóxico.

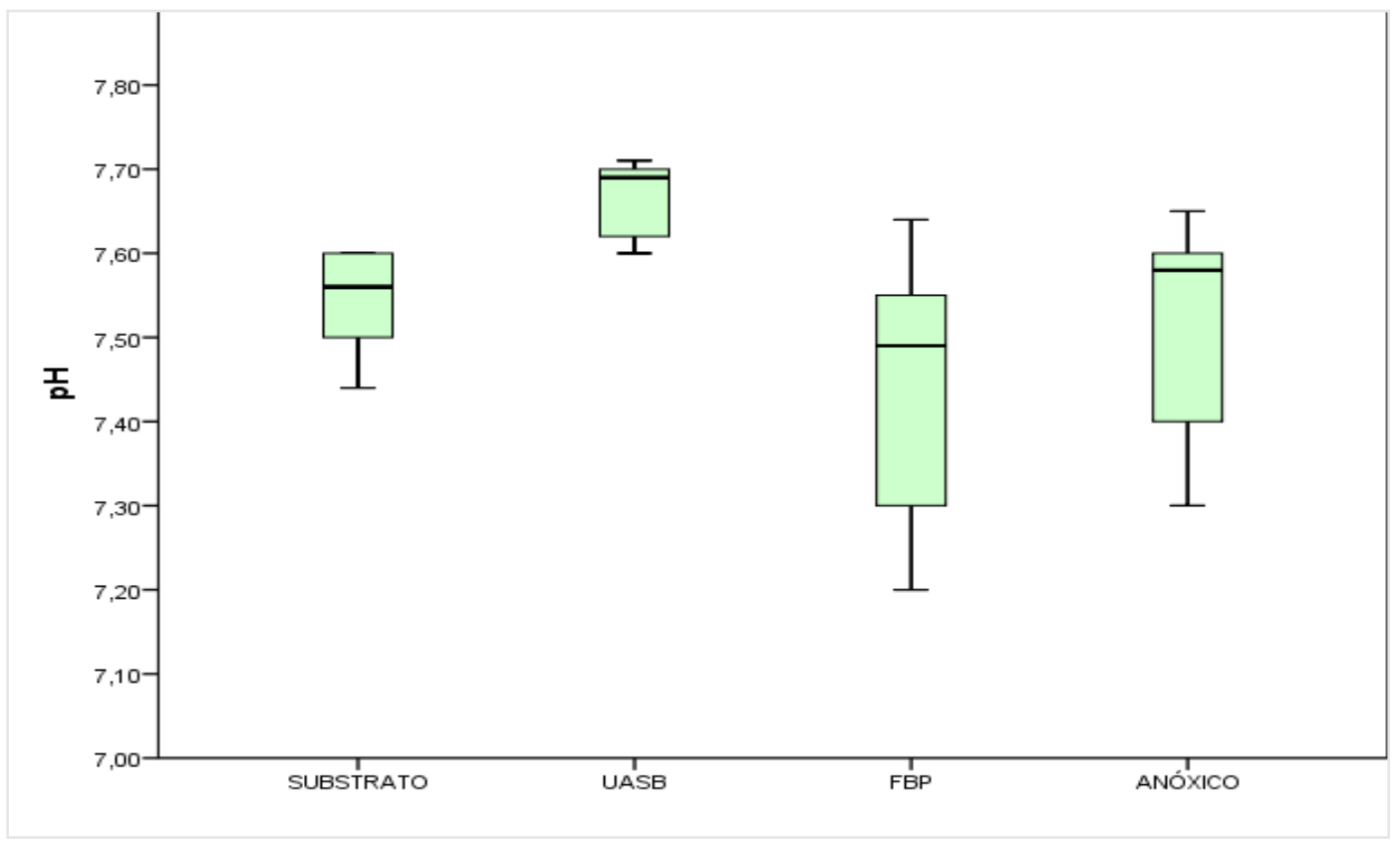

Fonte: Autores.

O valor de pH observado no FBP foi de 7,5. Esse valor indica que o processo de nitrificação não sofreu interferência desse parâmetro durante a fase experimental. Além disso, observa-se que houve redução nos valores do pH do efluente advindo do UASB em comparação com o pH do FBP, que foi de 7,7 para 7,5, respectivamente. Esse fato pode ser explicado devido ao 
metabolismo das bactérias nitrificantes, que durante a fase de oxidação da amônia, produzem ácidos $\left(\mathrm{H}^{+}\right)$e consumem alcalinidade. Monteiro et al., (2019), utilizaram em seus experimentos, um sistema composto por reator UASB seguido por um FBP. Durante a fase experimental, os autores não observaram variações significativas do $\mathrm{pH}$ entre o afluente e o efluente do FBP, correlacionando a esse fato, a inexistência de interferência no processo de nitrificação.

$\mathrm{Na}$ etapa de desnitrificação, as bactérias desnitrificantes podem reduzir sua eficiência metabólica em decorrência das variações de pH no meio. Em pH ácido, as enzimas que atuam transformação da molécula do nitrogênio, podem ser inativadas. Já em pH elevado, as bactérias desnitrificantes reduzem sua eficiência metabólica, e necessitam de mais tempo de adaptação no reator, até atingir a fase lag novamente. No entanto, observou-se no reator anóxico o aumento do pH em comparação com a etapa de nitrificação, com pH 7,6. Esse valor de pH observado no efluente do reator anóxico, indica a existência do processo de desnitrificação, devido à produção de alcalinidade que ocorre durante essa etapa.

\subsection{Alcalinidade Total}

A alcalinidade é um parâmetro fundamental em sistemas de tratamento de efluentes. Seu monitoramento e controle, torna-se indispensável, sendo responsável por tamponar meios aquosos, impedindo alterações do pH no meio. A alcalinidade indica a quantidade de íons na água capazes de neutralizar ácidos, sendo constituídos principalmente por bicarbonatos $\left(\mathrm{HCO}_{3}{ }^{-}\right)$, carbonatos $\left(\mathrm{CO}_{3}^{-}\right)$e hidróxidos $\left(\mathrm{OH}^{-}\right)$e a concentração de cada um deles é função do pH (Coelho et al., 2015).

A alcalinidade total observada no substrato, apresentou variação na concentração de $724,1 \mathrm{mgCaCO}_{3} \cdot \mathrm{L}^{-1}$ a 759,3 $\mathrm{mgCaCO} 3 \cdot \mathrm{L}^{-1}$, com concentração média de $739,8 \mathrm{mgCaCO}_{3} \cdot \mathrm{L}^{-1}$. Observou-se no efluente do reator UASB, aumento na concentração média da alcalinidade total de $772,6 \mathrm{mgCaCO} 3 \cdot \mathrm{L}^{-1}$, que representa um aumento de $32,8 \mathrm{mgCaCO}_{3} \cdot \mathrm{L}^{-1}$ na concentração total. Esses resultados indicam que o reator UASB apresentou boa capacidade de tamponamento. Campos et al., (2006) apresentaram resultados satisfatórios utilizando um reator UASB para tratamento de efluentes de suinocultura. Os autores obtiveram valores médios de alcalinidade no afluente do reator UASB de $811 \mathrm{mgCaCO}_{3} \cdot \mathrm{L}^{-1}$ e no efluente $815 \mathrm{mgCaCO}_{3} \cdot \mathrm{L}^{-1}$, atribuindo o aumento da alcalinidade no reator, a sua capacidade de tamponamento.

Em consonância com a redução do pH, o consumo e produção de alcalinidade pode ser observado na Figura 4. Os resultados obtidos, corroboram com a dinâmica dos processos globais de transformação do nitrogênio, indicando que as etapas de amonificação, nitrificação e desnitrificação ocorreram durante o experimento. 
Figura 4.Concentração de alcalinidade total quantificada no substrato e efluente de cada reator.

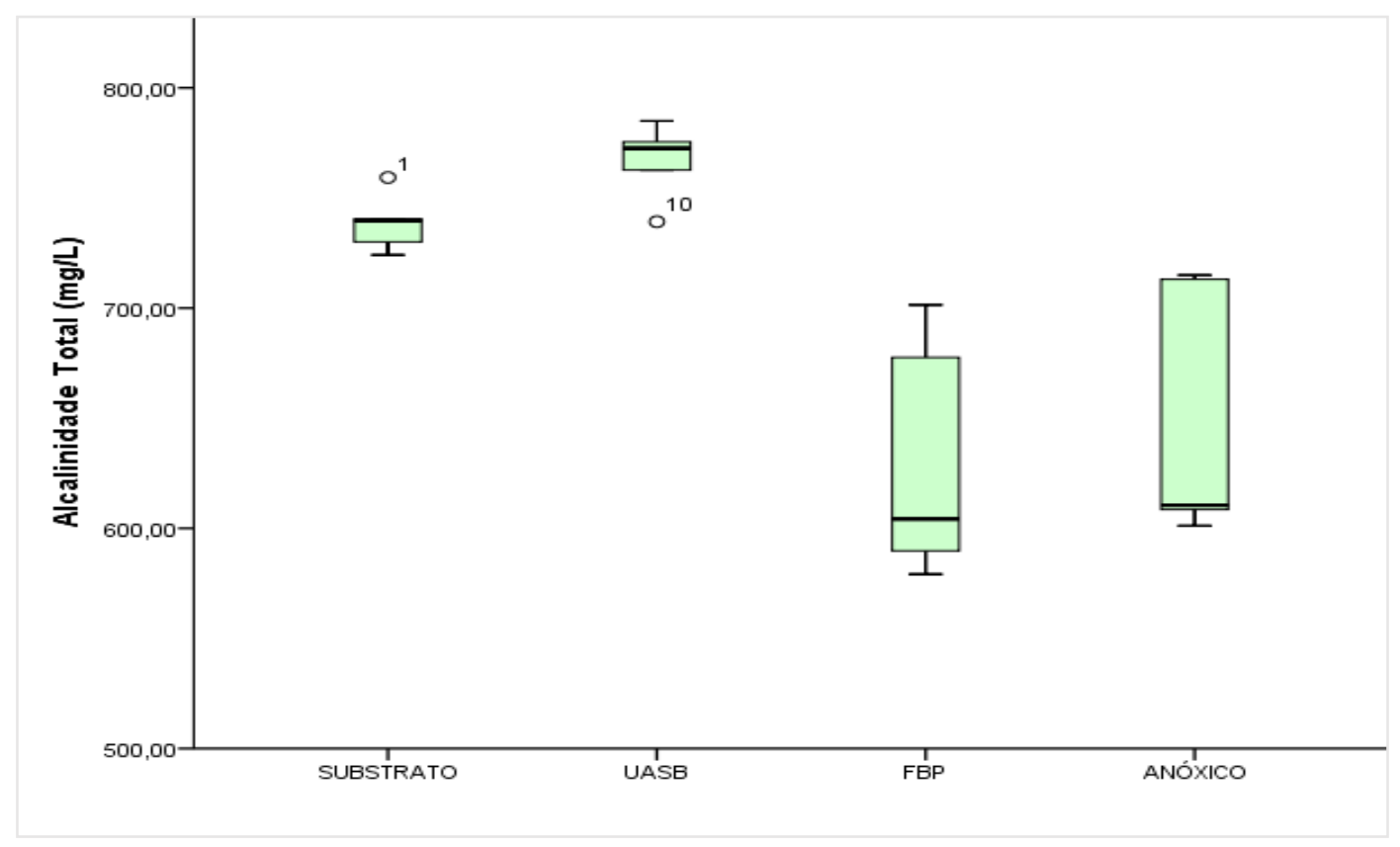

Fonte: Autores.

$\mathrm{Na}$ fase de acidogênese, etapa da digestão anaeróbia, os ácidos graxos voláteis, álcoois e compostos minerais, são formados como produtos intermediários durante a degradação dos carboidratos, proteínas e lipídeos (Campos et al., 2006). Além disso, durante a etapa de amonificação, a degradação de compostos orgânicos nitrogenados, contribui com a disponibilização de amônia no meio e produção de alcalinidade na forma de $\mathrm{OH}^{-}$.

Os valores de alcalinidade apresentaram redução em relação ao efluente advindo do reator UASB com valores de 772,6 $\mathrm{mgCaCO}_{3} \cdot \mathrm{L}^{-1}$, para $604,2 \mathrm{mgCaCO}_{3} \cdot \mathrm{L}^{-1}$ do efluente do FBP. O consumo de alcalinidade nessa etapa, relaciona-se com os processos de oxidação do nitrogênio amoniacal a nitrito e nitrato. Antileo et al., (2013), destacam que a redução do pH, ocorre principalmente em virtude da liberação de prótons durante a fase de nitrificação.

$\mathrm{O}$ reator anóxico, apresentou incremento na concentração de alcalinidade total no efluente durante o experimento. Em relação ao efluente do FBP, houve acréscimo da alcalinidade no efluente do reator anóxico de $6,2 \mathrm{mgCaCO}_{3} \cdot \mathrm{L}^{-1}$, apresentando valor médio em sua concentração total de $610,4 \mathrm{mgCaCO}_{3} \cdot \mathrm{L}^{-1}$. Esses valores indicam que o aumento da alcalinidade, foi em virtude da etapa de desnitrificação que ocorre durante à redução biológica das formas mais oxidadas do nitrogênio amoniacal (nitrito e nitrato) a nitrogênio gasoso. Com isso, pode haver aumento nos valores de $\mathrm{pH}$ no meio, em virtude da liberação de $\left(\mathrm{OH}^{-}\right)$elevando a alcalinidade do efluente.

\subsection{Nitrito e Nitrato}

Durante o monitoramento do sistema experimental, as concentrações de nitrito $\left(\mathrm{NO}_{2}^{-}\right)$e nitrato $\left(\mathrm{NO}_{3}{ }^{-}\right)$, variaram em decorrência da atividade bacteriana nitrificante no FBP. Observou-se que no FBP, as concentrações médias de nitrito $\left(\mathrm{NO}_{2}{ }^{-}\right)$e nitrato $\left(\mathrm{NO}_{3}{ }^{-}\right)$foi de $14,68 \mathrm{mg} . \mathrm{L}^{-1} \mathrm{e} 5,71 \mathrm{mg} . \mathrm{L}^{-1}$, respectivamente. A Figura 5, apresenta o comportamento do nitrito e do nitrato observado no efluente do FBP. 
Figura 5. Variação temporal das concentrações de nitrito (NO2-) e do nitrato (NO3-) no efluente do filtro biológico percolador (FBP).

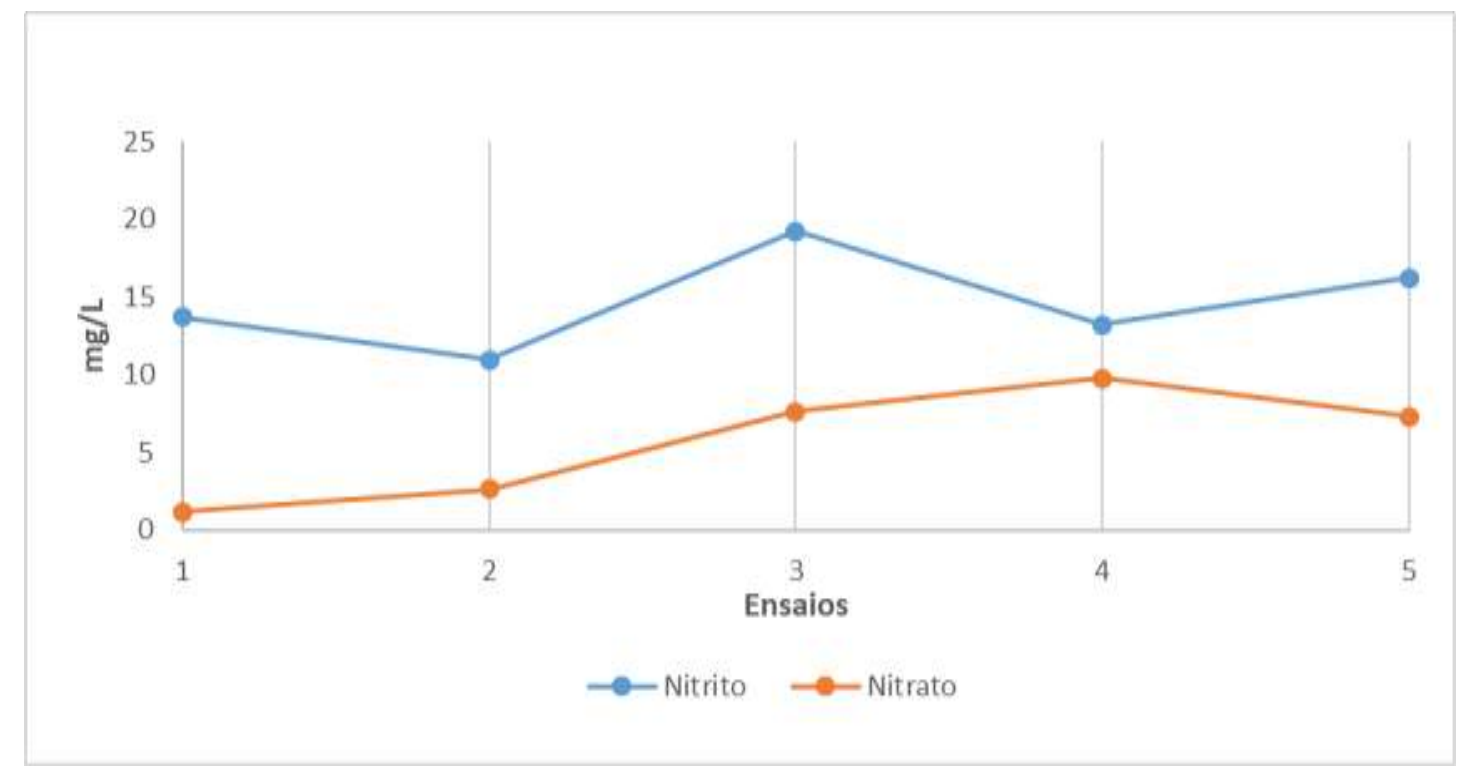

Fonte: Autores.

A elevada concentração de nitrito no FBP, demonstra que o sistema não favoreceu a atividade das oxidantes de nitrito durante o monitoramento do FBP. Acredita-se que essa condição ocorreu em virtude da disponibilidade de OD disponível no meio, ter sido insuficiente para promover uma nitrificação completa. He et al., (2007) destacam que o OD desempenha um papel importante no acumulo de nitrito no reator, porém ressalta-se que além dos níveis de OD, outros fatores como as características do efluente, condições operacionais e tecnologias utilizadas, são cruciais para o desempenho das oxidantes de nitrito.

Em sistemas de tratamento que utilizam reatores com biofilmes, a disponibilidade de OD no efluente do reator e sua difusão no biofilme, tem que ser suficiente para promover a etapa de nitrificação. Observou-se que no FBP, a etapa de nitrificação foi influenciada pela disponibilidade de OD, ocasionando o acúmulo de nitrito e possível inibição de BON por substrato. A concentração de nitrato aumentou com o tempo de operação do reator, em virtude da adaptabilidade de BON no FBP, pois esses microrganismos requerem maior tempo de crescimento na fase lag cerca de 1,08 $\mathrm{d}^{-1}$, em comparação a BOA 0,77 d $\mathrm{d}^{-1}$. Além disso, sabe-se que as BOA tendem a viver dispersas no efluente, em contrapartida, BON tende a se aderir em biofilmes e, metabolicamente, atingem melhores eficiências quando estão em sintrofia com as BOA, de onde podem obter diretamente o nitrito.

Ruiz et al., (2003) apresentaram a influência do OD na etapa de conversão da amônia a nitrito e do nitrito a nitrato. Os autores observaram que em níveis de OD de 1,7 mg/L a 5,7 mg/L, não houve interferência do OD na etapa de nitrificação. Porém, em concentrações de 1,4 mg/L, houve acúmulo de nitrito em decorrência da redução da concentração de OD. He et al., (2007) identificaram que níveis de OD entre 0,2-0,6 mg/L, são responsáveis por ocasionarem o acúmulo de nitrito em sistemas de tratamento, interferindo na etapa de nitrificação.

Desse modo, esses resultados apresentados na Figura 5, corroboram com a interferência do OD na etapa de nitrificação, tendo em vista que esse parâmetro é tido como um co-substrato nessa etapa, e a eficiência bacteriana na oxidação da amônia e do nitrito, está diretamente relacionada com a disponibilidade de oxigênio dissolvido no meio. 


\subsection{Quantificação das Bactérias Nitrificantes e Desnitrificantes pela Técnica de Número Mais Provável (NMP)}

A estimativa das densidades populacionais dos microrganismos atuantes nas etapas de transformação do nitrogênio, ocorreu através do uso da técnica do Número Mais Provável (NMP). As análises presuntivas das densidades populacionais dos grupos bacterianos, foram realizadas após a coleta do efluente no Filtro Biológico Percolador (FBP) e Reator Anóxico.

No primeiro ensaio, observa-se a variação populacional entre as oxidantes de amônia (BOA) e as oxidantes de nitrito (BON) com 1,4 x 10 NMP/100 ml e 0,7 x 10³ NMP/100 ml, respectivamente. A maior população de oxidantes de amônia pode estar relacionada ao processo de aeração proposto no FBP no início do experimento, tendo em vista que a concentração de OD é um fator limitante para o metabolismo bacteriano nitrificante. Nestes estágios iniciais, o oxigênio foi obtido de forma natural através de aberturas nas laterais do FBP com aproximadamente $20 \mathrm{~mm}$ de diâmetro. No entanto, observou-se que essa forma de aeração não foi suficiente para promover a etapa de nitrificação completa.

De acordo com Ferreira (2000), a taxa de crescimento das Nitrosomonas, organismo nitrificante responsável pela primeira etapa da nitrificação, não está limitada em níveis de OD acima de 1,0 mg/L, mas na prática, é requerido um OD maior do que 2,0 mg/L. Além disso, é recomendado que o nível mínimo de OD seja estipulado em 2,0 mg/L, em todo tempo e através do reator biológico, para se prever picos de carga de amônia no sistema experimental. A Figura 6 apresenta as variações populacionais observadas no primeiro ensaio, com as respectivas densidades populacionais dos grupos bacterianos estudados.

Figura 6. NMP dos grupos bacterianos identificados no $1^{\circ}$ ensaio.

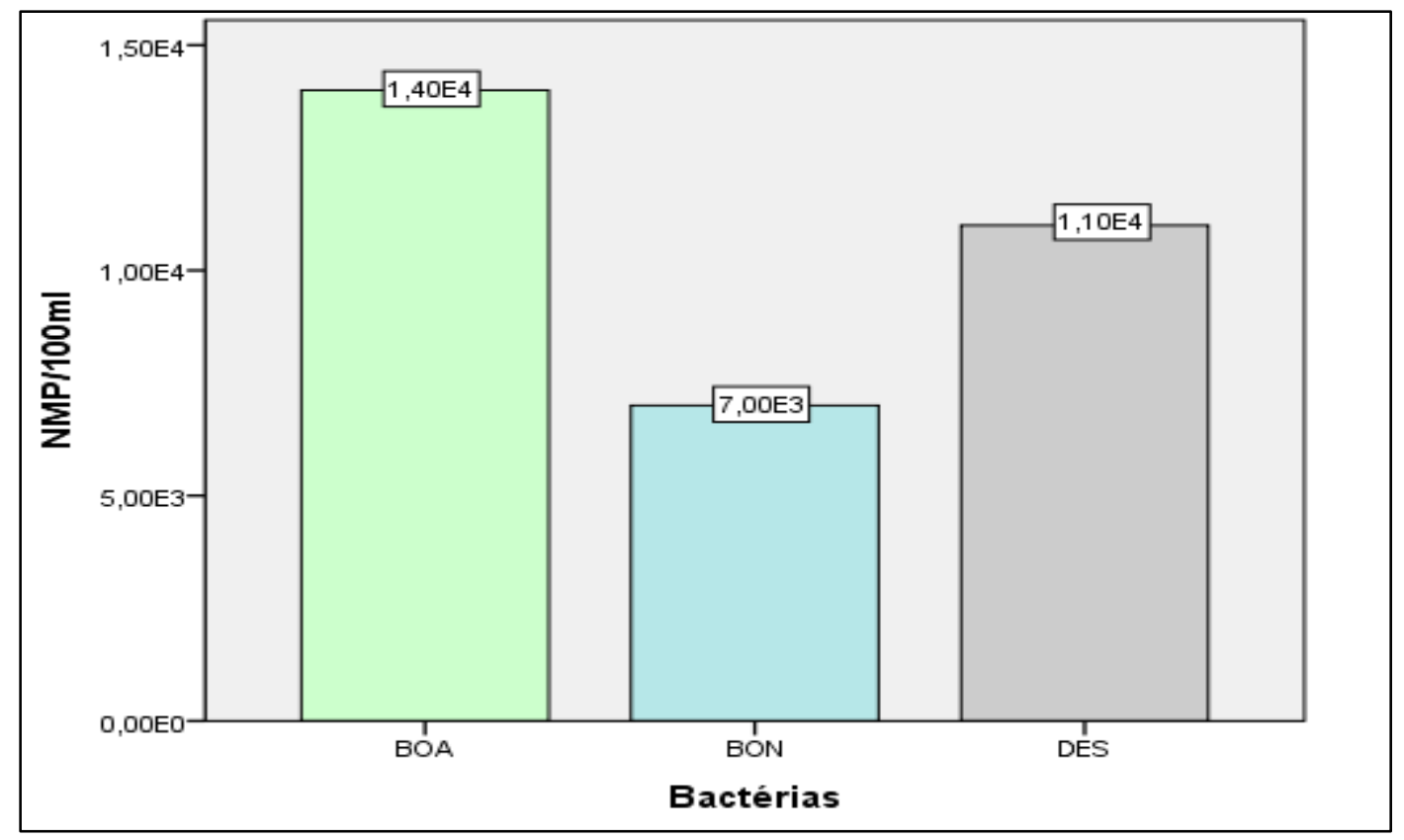

Fonte: Autores.

Além disso, a vantagem relativa da população inicial de BOA pode levar ao acúmulo de nitrito no sistema, refletindo diretamente no desenvolvimento de BON, conforme apresentado na Figura 6. Ferreira (2000), destaca que o nitrito pode acumular durante as reações de conversão do nitrogênio amoniacal quando a taxa de formação dos nitratos é superada pela taxa de geração dos nitritos. Essa condição pode ocorrer quando as bactérias nitrificantes estão em fase de aclimatação ou durante sua inoculação. Além do mais, o acúmulo do nitrito geralmente está associado a baixa eficiência de aeração, refletindo diretamente na eficiência metabólica de BON.

A densidade populacional de bactérias desnitrificantes observada neste ensaio é de $1,1 \times 10^{4} \mathrm{NMP} / 100 \mathrm{ml}$. O resultado observado nesta análise preliminar, pode ser associada a taxa de crescimento específico das bactérias heterotróficas que é superior 
ao das bactérias nitrificantes. Além disso, acredita-se que a dinâmica populacional dessas bactérias, pode ter sido influenciada pela disponibilidade de carbono orgânico no substrato, devido ao baixo teor de matéria orgânica biodegradável no lixiviado. Souza et al., (2005) enfatizam que a baixa disponibilidade de elétrons em compostos orgânicos (fontes de carbono) limitará o processo de desnitrificação e interferirá diretamente na dinâmica populacional dessas bactérias.

A quantidade de nitrogênio amoniacal disponível no sistema juntamente com o OD, irá fornecer condições para as bactérias oxidantes de amônia converter o N-NH $\mathrm{em} \mathrm{NO}_{2}{ }^{-}$e $\mathrm{NO}_{3}{ }_{3}$. Portanto, as suas respectivas concentrações no meio, poderá definir a velocidade do processo. Os resultados apresentados por Kim et al., (2005), indicam que a baixa eficiência da nitrificação pode ocorrer pela elevada concentração de $\mathrm{N}_{-} \mathrm{NH}_{4}{ }^{+}$no meio, podendo ocasionar o acúmulo de $\mathrm{N}_{-} \mathrm{NH}_{3}$ no reator e possível inibição do substrato por amônia livre. Além disso, a amônia livre pode atuar como inibidor de BON e, consequentemente, ser responsável pelo acumulo de nitrito no reator.

Segundo Vadivelu et al., (2007), essa inibição pode ocorrer através da ação direta da amônia sobre a enzima nitrito oxidoredutase ou sobre alguma outra enzima envolvida no transporte de elétrons, ou pela inibição do $\mathrm{NH}_{3}$ na produção de ATP, que pode representar um efeito semelhante na inibição. De fato, a concentração de amônia livre está associada aos valores de pH do meio. Entretanto, deve-se salientar que em reatores que utilizam biofilme, o valor de $\mathrm{pH}$ na fase liquida pode ser diferente do pH dentro do biofilme (Nocko, 2008).

Anthonisen et al., (1976), definem que a concentração de amônia livre necessária para inibir BOA é de cerca de 10 a $150 \mathrm{mgN} / \mathrm{L}$, e que a inibição de BON pode ocorrer com valores próximos a $10 \mathrm{mgN} / \mathrm{L}$. Os autores relatam que o ácido nitroso $\left(\mathrm{HNO}_{2}\right)$, pode apresentar papel inibitório de BON em concentrações entre 0,22 e 2,8 $\mathrm{mgN} / \mathrm{L}$. Entretanto, esses valores podem apresentar variações de acordo com o sistema utilizado e o tempo de operação. Wu et al., (2008) observaram a inibição da etapa de nitrificação, quando a concentração da amônia livre foi de 160 mgN/L, ocasionando o acúmulo de 97\% de nitrito no sistema, impossibilitando a atividade das bactérias nitrificantes.

Wei et al., (2014) observaram a influência do tempo de operação nas etapas de remoção do N-amoniacal. Em sua pesquisa utilizaram um reator de bateladas sequenciais (RBS), e identificaram que após um período entre 45 e 90 dias de operação, o sistema favoreceu a adaptação das bactérias nitrificantes. Foi verificado que o aumento da carga de $\mathrm{N}-\mathrm{NH}_{4}{ }^{+}$de 200 $\mathrm{mg} / \mathrm{L}$ para $300 \mathrm{mg} / \mathrm{L}$, não interferiu na eficiência do processo apresentando 94,8\% de remoção de $\mathrm{N}$-amoniacal, em virtude de as bactérias estarem aclimatadas no reator.

De fato, os resultados apresentados nos ensaios iniciais, podem ser atribuídos ao tempo de aclimatação das bactérias nitrificantes no FBP. Como o sistema experimental neste estágio, está em fase inicial de operação, acredita-se que a elevada concentração de $\mathrm{N}$-amoniacal possa ser explicada pela falta de adaptabilidade bacteriana. A eficiência média de remoção de nitrogênio foi de aproximadamente 16,42\% no FBP, com concentração de $136,4 \mathrm{mg} \mathrm{N}-\mathrm{NH}_{4}{ }^{+}$. $\mathrm{L}^{-1}$. Esses valores indicam que o acúmulo de nitrogênio amoniacal no efluente do FBP, foi devido baixa eficiência da etapa de nitrificação durante a etapa experimental. A eficiência do processo de oxidação biológica do nitrogênio apresentada pelo FBP, pode ser observada na Figura 7, em que é representada a quantidade de $\mathrm{N}$-amoniacal identificada no início de operação do reator e a quantidade final obtida no efluente do FBP. 
Figura 7. Comportamento da variação temporal da concentração de nitrogênio amoniacal na série de reatores.

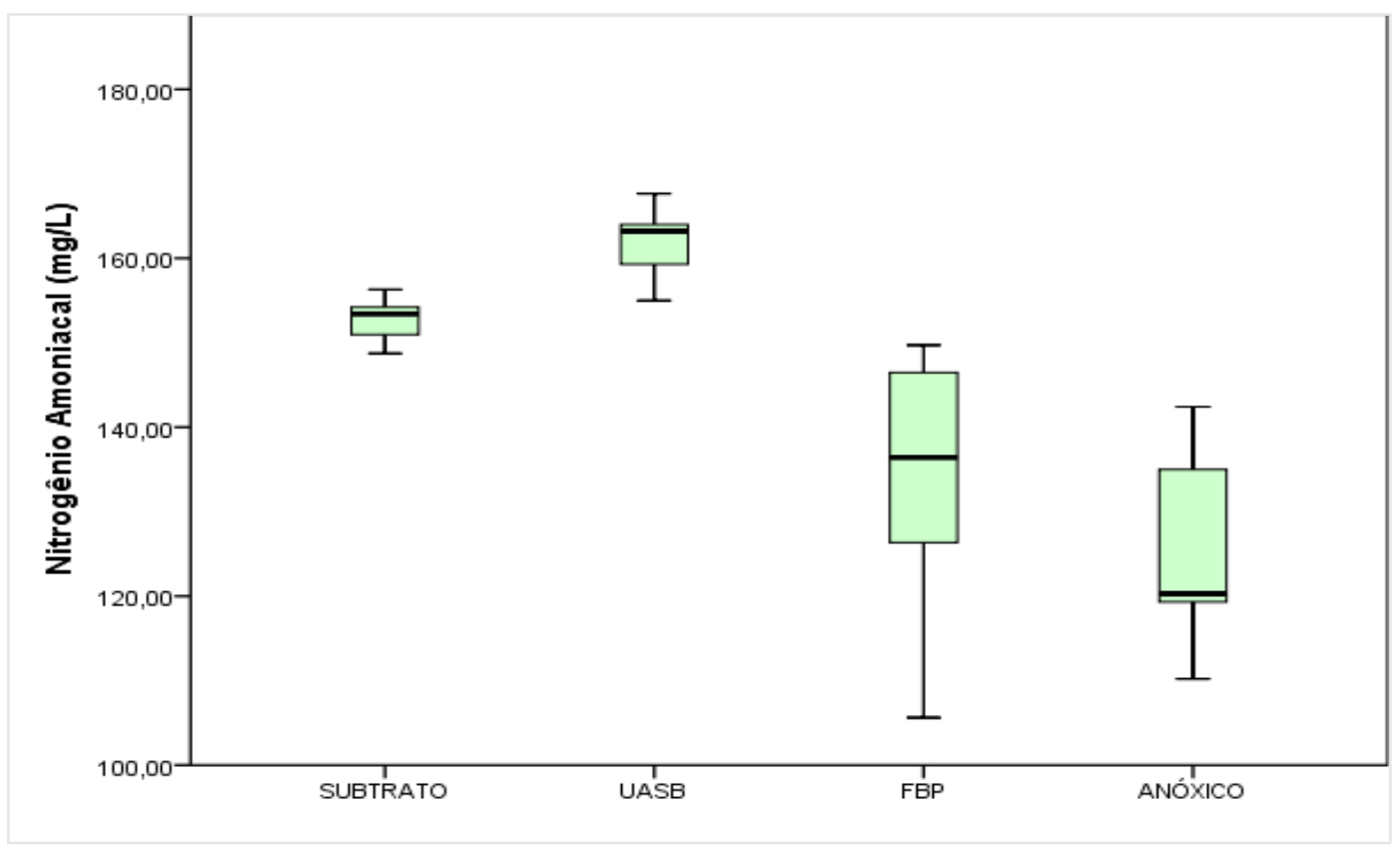

Fonte: Autores.

A elevada concentração de N-amoniacal pode ser atribuída a baixa concentração de OD durante as etapas iniciais do experimento, já que o oxigênio é requerido pelas bactérias nitrificantes durante a etapa de oxidação da amônia e do nitrito. Todavia, a baixa concentração de OD foi relacionado a forma de aeração do FBP nessas etapas iniciais, já que oxigênio era obtido de forma natural, por espaços nas laterais do FPB. Torres et al., (2009), destacam que o excesso de nitrogênio amoniacal pode provocar efeito inibitório nos processos biológicos em sistemas de tratamento de efluentes.

No entanto, assume-se que nesses estágios iniciais, as variações populacionais observadas entre BOA e BON podem ter relações com às condições ambientais e operacionais do sistema experimental. Veronese et al., (2013) atribuíram a interferência do O.D à baixa eficiência das bactérias nitrificantes. Os autores observaram que no estágio inicial do experimento, utilizando um biorreator de membranas (MBR), a baixa disponibilidade de oxigênio dissolvido, reduziu a eficiência de remoção do nitrogênio amoniacal em mais de $25 \%$. Além disso, a ausência de OD no reator aeróbio provocou a diminuição do valor do potencial de oxi-redução, indicando a ocorrência da inibição do processo de nitrificação.

Por outro lado, acredita-se que a baixa aeração no FBP, possa ter propiciado o estabelecimento de zonas anóxicas nos biofilmes aderidos ao material de suporte do FBP, podendo ter favorecido o metabolismo das bactérias desnitrificantes no biofilme, favorecendo positivamente a densidade populacional desse grupo bacteriano nesta fase. Esse efeito da baixa aeração foi confirmado por Monteiro et al., (2019). Os autores utilizando um sistema composto reator UASB seguido por FBP, identificaram que a baixa transferência de oxigênio no FPB, propiciou um sistema anóxico ou anaeróbio, acarretando em uma eficiência de tratamento reduzida, em função da adaptação da biomassa presente.

$\mathrm{Na}$ análise seguinte, observou-se a variação de BOA e BON em relação ao primeiro ensaio. As oxidantes de nitrito declinaram de $0,7 \times 10^{3} \mathrm{NMP} / 100 \mathrm{ml}$ para $0,8 \times 10^{2} \mathrm{NMP} / 100 \mathrm{ml}$. Esse fato foi atribuído a grande quantidade de nitrito no meio em virtude da elevada atividade de BOA, e da baixa estabilidade do biofilme. Observou-se que durante essa fase, quando era realizada a alimentação do reator com o substrato, ocorria o arraste da biomassa aderida e, consequentemente, o desprendimento do biofilme. Dessa forma, o NMP de BON pode ser explicado, devido a ecologia das oxidantes de nitrito ser favorecida quando estão em sintrofia no biofilme com as oxidantes de amônia.

Em regiões de clima mais quente, como no nordeste do Brasil, as taxas de nitrificação em sistemas de tratamento podem 
reduzir em virtude de a atividade dessas bactérias serem inibidas em temperaturas mais elevadas. Essa diferença populacional entre BOA e BON, pode ser explicada pelo fato de que em altas temperaturas, as bactérias do gênero Nitrobacter, responsáveis pela nitratação, apresentam uma taxa de crescimento significativamente menor que as bactérias do genêro Nitrosomonas, que atuam na primeira etapa da nitrificação (Verstraete \& Philips, 1998). Essas bactérias apresentam uma ecofisiologia distinta, divergindo na taxa de crescimento celular. Zoppas et al., (2016) destacam que o coeficiente de crescimento celular das oxidantes

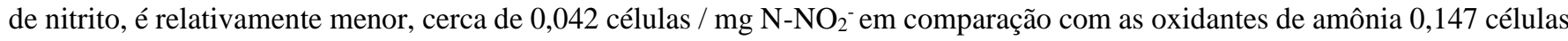
/ $\mathrm{mg} \mathrm{N}-\mathrm{NH}_{4}{ }^{+}$.

Ferreira (2000), destaca que essa variação populacional pode ser atribuída a concentração dos substratos dentro do biofilme, e sua difusão desde a superfície do biofilme e através dele. As respectivas concentrações de OD como para o nitrogênio amoniacal, podem resultar em baixas taxas de nitrificação, ocasionando variações populacionais entre BOA e BON. Os resultados apresentados por Liu et al., (2017), demonstraram que a inibição da atividade metabólica de BON, ocorre em virtude da baixa disponibilidade de OD, favorecendo o acumulo de nitrito no reator. Na Figura 8, observa-se o NMP dos grupos bacterianos caracterizados no segundo ensaio.

Figura 8. NMP dos grupos bacterianos presentes no $2^{\circ}$ ensaio.

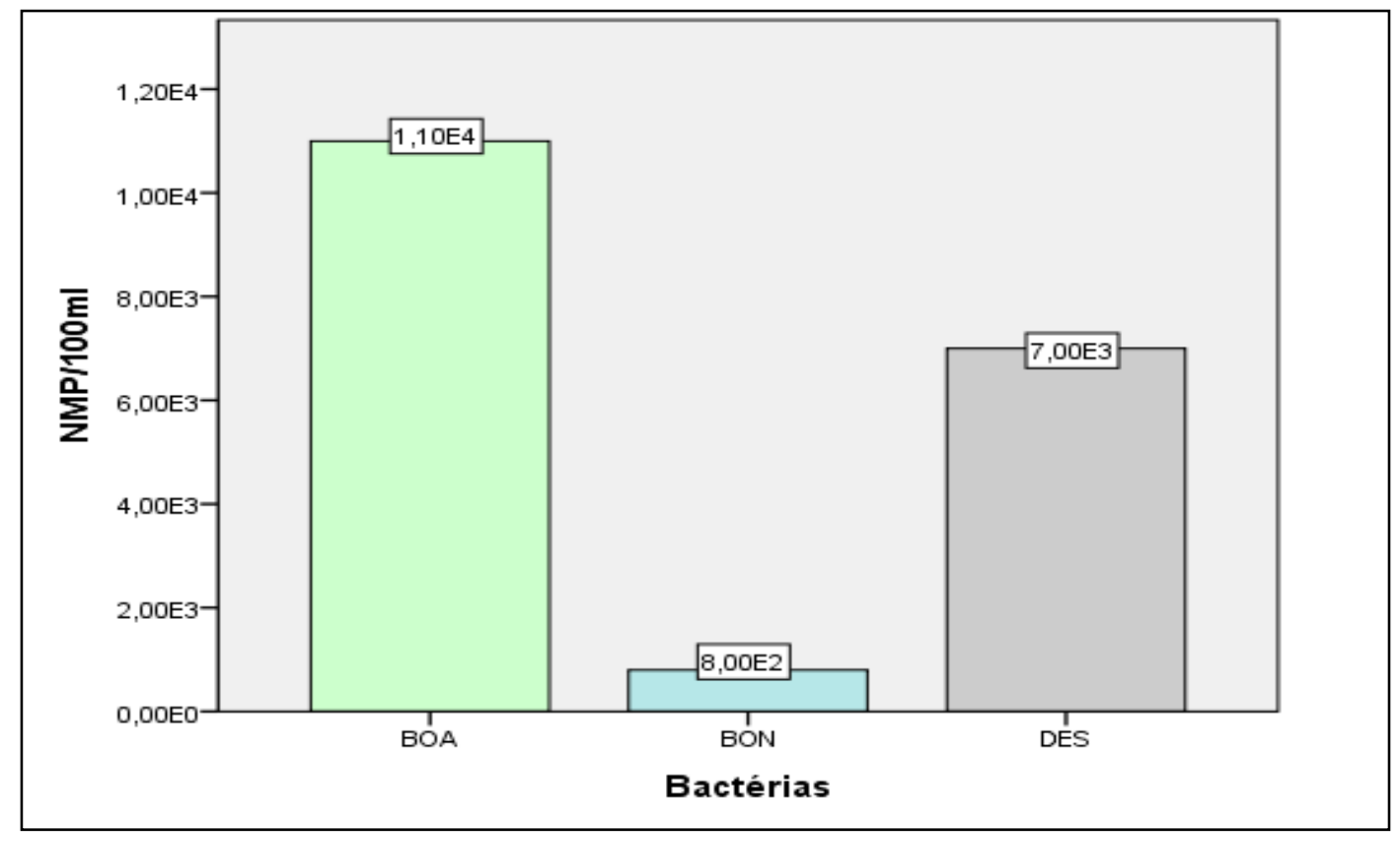

Fonte: Autores.

Os resultados obtidos nos ensaios iniciais, conforme apresentado nas Figuras 6 e 8, demonstraram maior atividade de BOA em relação a BON. Esse fenômeno pode ser explicado pelos altos valores requeridos de OD pelas bactérias nitrificantes durante a fase de oxidação do nitrogênio amoniacal. Os valores estequiométricos da quantidade oxigênio requerido pelas bactérias nitrificantes na oxidação de um mol de amônia equivale a 4,57 mg/ $\mathrm{O}_{2}$. Na oxidação da amônia a nitrito, o oxigênio requerido pelas oxidantes de amônia é cerca de $3,43 \mathrm{mg} / \mathrm{O}_{2}$, valor superior quando comparado a oxidação do nitrito a nitrato 1,14 $\mathrm{mg} / \mathrm{O}_{2}$, refletindo em um alto consumo de OD durante a primeira etapa da nitrificação. Esse consumo de oxigênio na primeira etapa, aliado a baixa disponibilidade de oxigênio no FBP, refletiu diretamente no crescimento populacional de BON, haja vista a oxigenação do FBP ter sido insuficiente para promover uma etapa de nitrificação completa.

Ferreira (2000), ressalta que durante a oxidação da amônia, o processo requer quantidades significativas de oxigênio, produz pouca quantidade de biomassa e resulta em um substancial consumo da alcalinidade, através da produção de íons 
hidrogênio. Além disso, o autor destaca que durante a síntese e oxidação de $50 \mathrm{mg} / \mathrm{L}$ de N-NH , ocorre o consumo de 216,0 $\mathrm{mg} / \mathrm{L}$ de oxigênio, produção cerca $6,50 \mathrm{mg} / \mathrm{L}$ de organismos nitrificantes e consumo de $353,5 \mathrm{mg}$ de alcalinidade na forma de $\mathrm{CaCO}_{3}$. Como observado, o consumo de oxigênio é elevado durante a etapa de nitrificação. Porém, em virtude da menor taxa de crescimento específico das bactérias do gênero Nitrosomonas (BOA) de $0,77 \mathrm{~d}^{-1} \mathrm{em}$ comparação com o gênero Nitrobacter (BON) que é 1,08 $\mathrm{d}^{-1}$, o maior consumo de oxigênio pelas bactérias nitrificantes, está relacionado com a velocidade de crescimento das bactérias responsáveis pela primeira etapa da nitrificação, proporcionando um maior NMP das oxidantes de amônia nessas etapas.

Além disso, acredita-se que a etapa de alimentação do FBP pode ter influenciado na instabilidade dos grupos bacterianos durante esta fase no reator, ocasionando variações nas populações de BOA e BON. Isso pode ter ocorrido em virtude da descarga do substrato utilizado na alimentação do FBP, não ter percolado como proposto pela configuração do reator, causando o desprendimento do biofilme e o arraste da biomassa aderida durante essa fase.

As bactérias heterotróficas desnitrificantes também apresentaram variações populacionais nesse estágio inicial. Conforme apresentado nas Figuras 6 e 8, foi observado o declínio populacional dessas bactérias de 1,1x104 NMP/100 ml para $0,7 \mathrm{X} 10^{3} \mathrm{NMP} / 100 \mathrm{ml}$. A variação populacional observada nesta etapa pode ser explicada devido à redução na densidade populacional de BON, resultando em variações na concentração de nitrato no meio. Ou seja, a quantidade de matéria orgânica degradável e os receptores de elétrons, produtos gerados pela oxidação da amônia na etapa de nitrificação $\left(\mathrm{NO}_{3}{ }^{-} ; \mathrm{NO}_{2}{ }^{-}\right)$, refletem no crescimento dessas bactérias. Mangili et al., (2010), observaram a variação populacional dessas bactérias, utilizando sistema experimental composto por dois reatores (anóxico e aeróbio). Os autores identificaram que quando NMP das bactérias desnitrificantes eram inferiores ao das bactérias nitrificantes, foi justificado pela baixa concentração de receptor de elétrons $\left(\mathrm{NO}_{3}{ }^{-}\right.$ e $\mathrm{NO}_{2}{ }^{-}$, presente no meio), em função do metabolismo quimiolitotrófico nitrificante, apresentar velocidade de crescimento menor que as heterotróficas.

No terceiro ensaio observou-se o declínio populacional de BOA em relação a população BON. As variações populacionais apresentadas nesta etapa, podem ser relacionadas com as alterações realizadas na etapa de aeração do FBP, indicando a maior adaptabilidade de BON no FPB. Como a maturação do biofilme ocorre com a extensão do tempo de operação do sistema, esta fase de operação pode ter sido benéfica para o sucesso ecológico das populações de BON, pois essas bactérias tendem a viver aderidas aos biofilmes.

Com o declínio populacional de BOA nesta fase, consequentemente a quantidade de nitrito reduziu no meio. Uma vez que o acúmulo de nitrito levará à inibição das populações de BON, o ensaio mostra que em comparação com os ensaios 1 e 2, a densidade populacional BON é significativamente maior. Oliveira et al., (2013), também obtiveram resultados semelhantes operando um reator aeróbio seguido por reator anóxico, tratando lixiviado de aterro sanitário. Os autores apresentaram tempo de monitoramento do sistema experimental semelhante ao apresentado neste estudo, atribuindo o aumento do NMP de BON a redução da concentração de nitrito e, consequentemente, o decréscimo no NMP de BOA, caracterizando a maior atividade de BON no do FBP nesta etapa. 
As bactérias desnitrificantes observadas no terceiro ensaio, representadas na Figura 9, apresentaram aumento na densidade populacional, com 1,4×104 NMP/100ml, em relação ao ensaio anterior. Alves et al., (2018), atribuem esse crescimento a alta velocidade de crescimento específico desse grupo $\left(\mu \max =7,2 \mathrm{~d}^{-1}\right)$, sendo considerados maiores quando comparados com crescimento especifico das bactérias nitrificantes. Além disso, esse crescimento populacional observado pode ter sido favorecido pela maior atividade de BON no reator, que contribuiu diretamente com o aumento da concentração de nitrato meio, seu principal aceptor de elétrons na cadeia respiratória.

Figura 9. NMP dos grupos bacterianos identificados no $3^{\circ}$ ensaio.

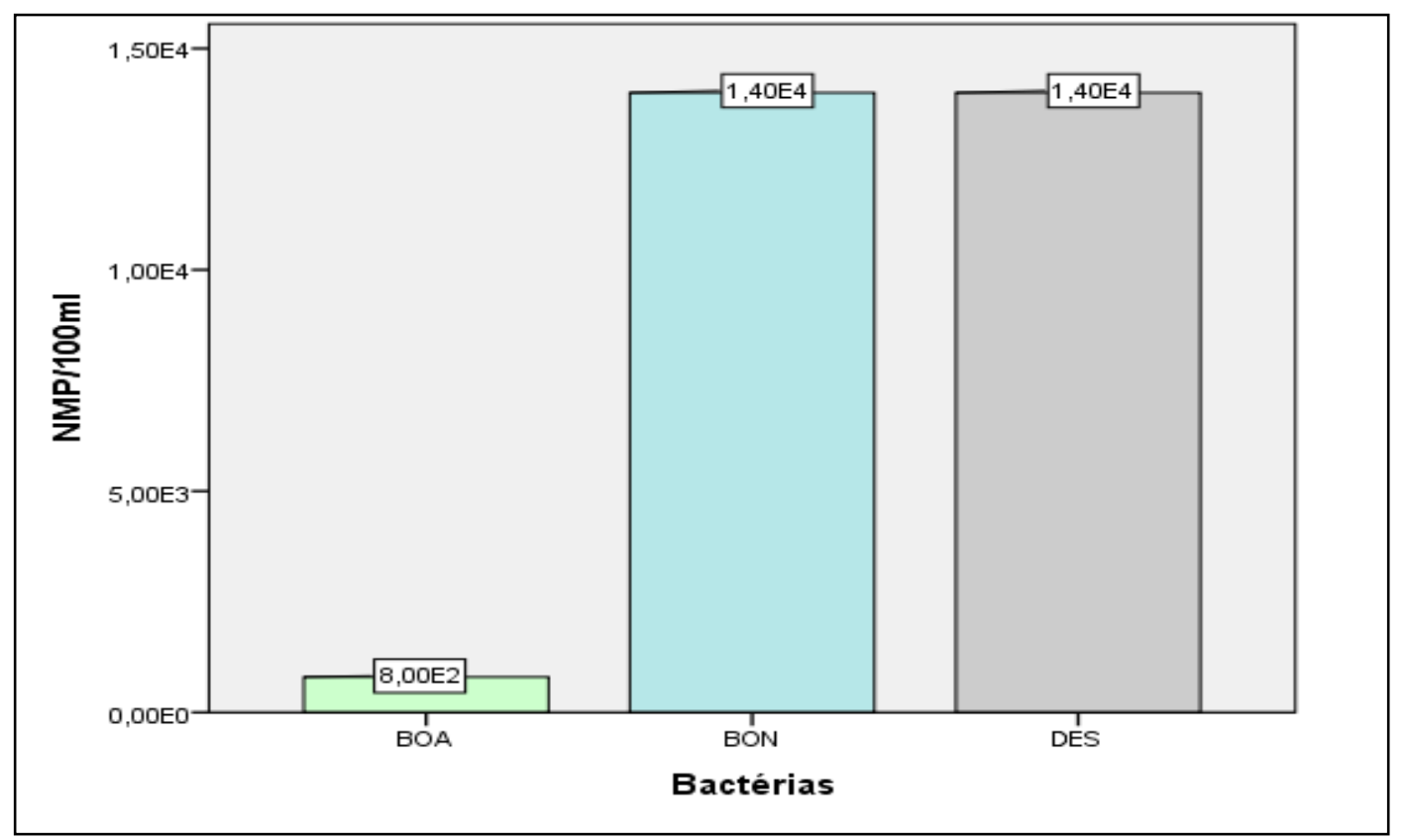

Fonte: Autores.

O ensaio 4, demonstrou outro pico de crescimento de BOA no FBP, como mostra a Figura 10. Isso pode ser explicado pela redução da carga nitrogenada introduzida no FBP, e pelo tempo de operação do sistema, devido a maior adaptabilidade bacteriana ao FBP. As BON, também apresentaram maior pico de densidade populacional com NMP de 1,4x104 NMP/100ml. O crescimento de BOA e BON nessa análise, pode ser atribuída ao grau de maturidade do biofilme e a redução no arraste da biomassa e desprendimento do biofilme na fase de alimentação. Isso foi atribuído a adição de uma camada de $10 \mathrm{~cm}$ de areia no FBP, reduzindo o impacto ao biofilme observado no início das análises.

As populações das bactérias desnitrificantes não apresentaram variações durante essa fase. O NMP das bactérias

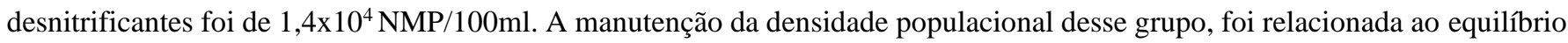
populacional de BON que mantiveram, teoricamente, as concentrações de nitrato estáveis no sistema. Os equilíbrios populacionais observados nessas etapas, destacam que a eficiência na etapa de desnitrificação, pode ser considerada baixa quando comparadas aos resultados obtidos por Oliveira et al. (2013). Os autores obtiveram valores de $3,3 \times 10^{5} \mathrm{NMP} / 100 \mathrm{ml}$ para $2,4 \times 10^{10}$ NMP/100ml, quando utilizaram uma fonte de carbono externa no sistema. Destacando que, o uso da fonte externa de carbono é necessário para promover uma desnitrificação eficiente, principalmente quando se trata de um substrato de alta complexidade como o lixiviado.

Sundberg et al., (2007), observaram limitação no crescimento das bactérias desnitrificantes, quando promoveram a desnitrificação utilizando lixiviado como substrato. Os autores atribuem essa limitação no crescimento bacteriano, a influência direta da biodegradabilidade da matéria orgânica, disponibilidade de oxigênio e a concentração de nitrato. 
Kim et al., (2005), utilizando um reator de biofilme, identificaram que as oxidantes de amônia e oxidantes de nitrito puderam crescer em equilíbrio sem limitação de oxigênio e inibição de amônia livre até alcançar o equilíbrio em suas atividades e números populacionais. Os autores atribuiram esse equilibrio populacional ao tempo de operação do sistema além do controle da carga aplicada do $\mathrm{N}$-amonical. Esses resultados, corroboraram com os resultados demonstrados neste ensaio, como apresentado na Figura 10.

Figura 10. NMP dos grupos bacterianos identificados no $4^{\circ}$ ensaio.

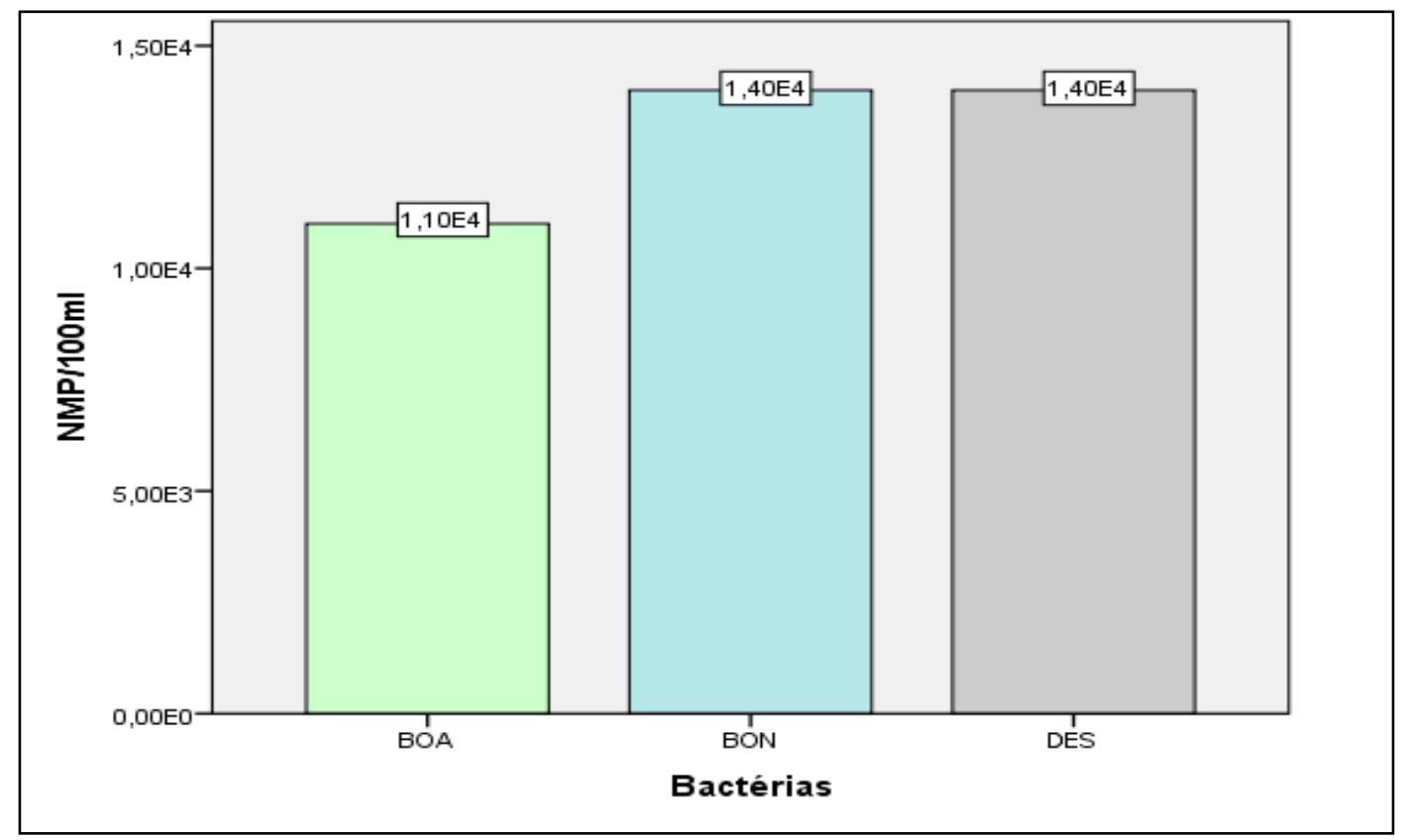

Fonte: Autores.

Dessa forma, após o sistema experimental passar por adaptações como, reduções na carga $\mathrm{N}$-amoniacal, alterações no processo aeração, tempo de operação e, consequentemente, maior estabilidade do biofilme, foi possível observar crescimento no NMP das bactérias nitrificantes durante o monitoramento do sistema experimental.

$\mathrm{O}$ quinto ensaio demonstrou que adaptabilidade das bactérias nitrificantes foi crescente no decorrer do monitoramento do sistema experimental. Isso demostra que o FBP, após as alterações nos parâmetros operacionais, favoreceu a dinâmica populacional das bactérias nitrificantes. As populações de BOA e BON apresentaram densidades populacionais superiores, com $1,4 \times 10^{5} \mathrm{NMP} / 100 \mathrm{ml}$ e $2,2 \times 10^{4} \mathrm{NMP} / 100 \mathrm{ml}$, respectivamente. Nesse estágio do experimento, a adaptação continua da biomassa foi favorável para manutenção do equilíbrio populações das oxidantes de nitrito e oxidantes de nitrato. A inserção da aeração mecânica, possibilitou um melhor desempenho das bactérias nitrificantes na oxidação dos seus respectivos substratos, amônia e nitrito.

As populações bacterianas desnitrificantes também apresentaram crescimento durante essa fase. Esses resultados corroboram com os resultados apresentados por Oliveira et al., (2013). Os autores destacam que mesmo as características do lixiviado apresentarem baixa concentração de matéria orgânica de fácil biodegradação, foi observado crescimento das populações desnitrificantes durante as fases inicias experimento, quando não houve adição de fonte externa de carbono. Esse crescimento das bactérias desnitrificantes, pode ser relacionado ao crescimento das bactérias oxidantes de nitrito, já que o produto da oxidação dessas bactérias, é utilizado como aceptor de elétrons na cadeia respiratória. A Figura 11 apresenta o NMP dos grupos bacterianos nitrificantes e desnitrificantes observados neste ensaio. 
Figura 11. NMP dos grupos bacterianos identificados no $5^{\circ}$ ensaio.

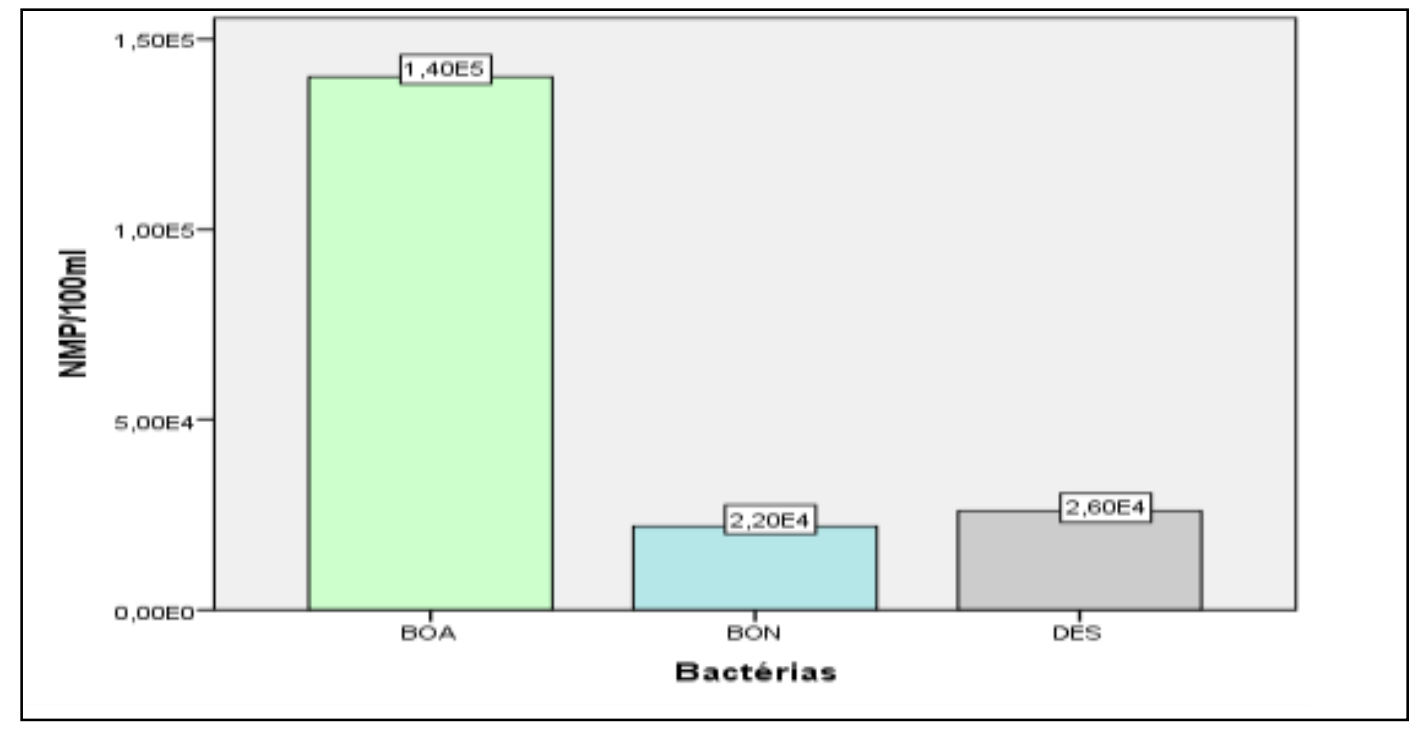

Fonte: Autores.

Trois et al., (2010) destacam que a composição do substrato, natureza, razão carbono/nitrogênio (C/N) e o grau de maturidade e estabilidade do biofilme, desempenham um papel fundamental no processo de desnitrificação, impactando diretamente no desenvolvimento da população bacteriana, e na eficiência de remoção de nitrato a longo prazo.

\section{Considerações Finais}

Analisando os dados deste trabalho, pode ser constatado que o NMP dos grupos bacterianos demonstrou que o sistema experimental tem capacidade para realizar os processos de nitrificação e desnitrificação. O NMP das bactérias oxidantes de

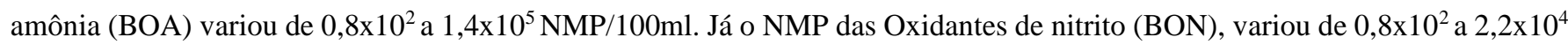
NMP/100ml.

As densidades populacionais observadas entre os grupos bacterianos nitrificantes, foram fortemente influenciadas pelos parâmetros operacionais durante o monitoramento do sistema experimental, refletindo diretamente na etapa de oxidação do nitrogênio. Observou-se interferência direta do OD, N-amoniacal e o tempo de maturação do biofilme na determinação do NMP das bactérias nitrificantes, sendo o a limitação da concentração de OD, o principal interferente observado na etapa de oxidação do nitrogênio amoniacal e do nitrito.

Com a extensão do tempo de operação do sistema experimental, maturação do biofilme no FBP e inserção da aeração mecânica, foi possível observar aumento no NMP dos ensaios 4 e 5, o que certamente favoreceu a ecologia das bactérias nitrificantes.

O NMP das bactérias desnitrificantes foi dependente da etapa de nitrificação, tendo em vista que o nitrato é utilizado pelas bactérias desnitrificantes, como aceptor final de elétrons durante a respiração anóxica. A estimativa populacional das

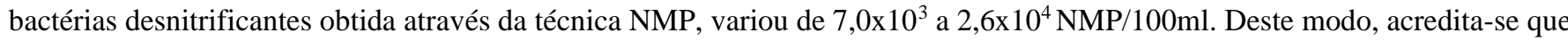
a etapa de desnitrificação, foi influenciada pela disponibilidade de nitrato e de carbono orgânico presente no substrato, indicando que o sistema necessita de melhorias no processo de aeração para favorecimento das bactérias nitrificantes, além da adição de uma fonte externa de carbono orgânico, para garantir maiores eficiências durante a redução do $\mathrm{NO}_{3}{ }^{-}$a $\mathrm{N}_{2}$.

De acordo com os resultados obtidos durante o monitoramento do sistema experimental, pode-se concluir que o tratamento conjugado de lixiviado de aterro sanitário e esgoto doméstico, utilizando reatores em série, demonstraram capacidade 
de tratamento de efluentes de composição complexas. A eficiência do reator UASB no processo de conversão do nitrogênio orgânico a nitrogênio amoniacal, durante a etapa de amonificação, foi de 6,4\%. Esse valor representou um acréscimo de 9,8 $\mathrm{mgN} / \mathrm{L}$ de nitrogênio amoniacal no efluente do UASB, durante esta etapa.

Em suma, pode-se a afirmar que o processo de remoção biológica de nitrogênio observado no FBP durante a etapa de nitrificação, apresentou eficiência média de $16,4 \%$, gerando um efluente com concentração média de $136,4 \mathrm{mg} \mathrm{N}-\mathrm{NH}_{4}{ }^{+} \cdot \mathrm{L}^{-1}$ no FBP. Esses valores corroboram com a baixa eficiência da etapa de nitrificação durante a etapa de oxidação nitrogênio. A baixa disponibilidade de OD foi atribuída ao processo de aeração que ocorria de forma natural no FBP, proporcionando em baixas taxas de remoção de nitrogênio durante o monitoramento do sistema experimental. Esses resultados indicam que o FBP necessita da inserção da aeração mecânica para fornecer quantidades de OD suficientes para suprir o metabolismo aeróbio das bactérias nitrificantes.

Nesse sentido, o conhecimento sobre a composição e adaptabilidade bacteriana em biorreatores é fundamental. O progresso de novas pesquisas e o desenvolvimento de novos processos de tratamento, está associado avanço no conhecimento da ecologia desses microrganismos, uma vez que para se atingir maiores eficiências de tratamento, necessita-se do controle rigoroso dos parâmetros operacionais e do conhecimento sobre os principais fatores que favorecem as etapas de nitrificação e desnitrificação.

\section{Referências}

Alves, C. F., Bortoluci, C. B. C., Oliveira, E. P., Pizzo, M. M., \& Rodriguez, R. P. (2018). Remoção biológica de nitrogênio em águas residuárias: uma revisão dos processos convencionais aos processos modernos. Revista Ibero-Americana de Ciências Ambientais, 9(3), $174-187$.

Anthonisen, A. C., Loehr, R. C., Prakasam, T. B. S., \& Srinath, E. G. (1976). Inhibition of nitrification by ammonia and nitrous acid. Journal (Water Pollution Control Federation), 835-852.

Antileo, C., Medina, H., Bornhardt, C., Muñoz, C., Jaramillo, F., \& Proal, J. (2013). Actuators monitoring system for real-time control of nitrificationdenitrification via nitrite on long-term operation. Chemical Engineering Journal, 223, 467-478.

Apha, A. (2012). American Public Health Association Standard Methods for Examination of Water and Wastewater. 19. Washington: Apha, Awwa, Wpcf.

Campos, C. M. M., Carmo, F. R. D., Botelho, C. G., \& Costa, C. C. D. (2006). Development and operation of an upflow anaerobic sludge blanket reactor (UASB) treating liquid effluent from swine manure in laboratory scale. Revista Ciência e Agrotecnologia, 30, 140-147.

Ceballos, B. S. O., \& Diniz, C. R. (2017). Técnicas de microbiologia sanitária e ambiental: EDUEPB.

Christensen, T. H., Kjeldsen, P., Bjerg, P. L., Jensen, D. L., Christensen, J. B., Baun, A., \& Heron, G. (2001). Biogeochemistry of landfill leachate plumes. Applied geochemistry, 16(7-8), 659-718.

Coelho, D. A, Silva, A. R. S., \& Castro, T. O. (2015). Análise da alcalinidade total e concentração de carbono inorgânico em trechos urbanos de rios: o exemplo do rio santa rita, região sudoeste da Bahia. In: Anais do VI congresso Brasileiro de Gestão Ambiental. Porto Alegre, RS. IBEAS.

Ferreira, E. S. (2000). Cinética química e fundamentos dos processos de nitrificação e desnitrificação biológica. In: congresso interamericano de engenharia sanitária e ambiental, 27., Porto Alegre. Anais: ABES, 2000.

Fleck, L., Tavares, M. H. F., \& Eyng, E. (2015). Remoção biológica de nitrogênio em efluentes líquidos: uma revisão. Revista Eixo, 4(2).

He, Y., Zhou, G., \& Zhao, Y. (2007). Nitrification with high nitrite accumulation for the treatment of "Old" landfill leachates. Environmental engineering science, 24(8), 1084-1094.

Kim, D. J., Ahn, D. H., \& Lee, D. I. (2005). Effects of free ammonia and dissolved oxygen on nitrification and nitrite accumulation in a biofilm airlift reactor. Korean Journal of Chemical Engineering, 22(1), 85-90.

Kim, D. J., Lee, D. I., \& Keller, J. (2006). Effect of temperature and free ammonia on nitrification and nitrite accumulation in landfill leachate and analysis of its nitrifying bacterial community by FISH. Bioresource technology, 97(3), 459-468.

Leite, V. D., Lopes, W. S., Sousa, J. T., de Albuquerque, M. V. C., Silva, M. C. C. de P. e., Cartaxo, A. S. B., \& Dantas, G. D. (2021). Urban solid waste in the State of Paraíba and the context of environmental sustainability. Research, Society and Development, 10(1), e33110111781. https://doi.org/10.33448/rsdv10i1.11781.

Liu, J., Yuan, Y., Li, B., Zhang, Q., Wu, L., Li, X., \& Peng, Y. (2017). Enhanced nitrogen and phosphorus removal from municipal wastewater in an anaerobicaerobic-anoxic sequencing batch reactor with sludge fermentation products as carbon source. Bioresource technology, 244, 1158-1165. 
Mangili, F. B., Jacobs, A. C. P., Maroubo, L. A., Lopes, D. D., \& Prates, K. V. M. C. (2010). Caracterização e quantificação de microrganismos em sistema de remoção biológica de nitrogênio de lixiviado de aterro. In: Congresso Brasileiro de Engenharia Sanitária e Ambiental. 26., Porto Alegre. Anais: ABES.

Mendonça, L. C. (2002). Microbiologia e cinética de sistemas de lodos ativados como pós-tratamento de efluente de reator anaeróbio de leito expandido. 2002, 184F. Tese (Doutorado) Universidade de São Paulo, São Carlos.

Metcalf, L., \& Eddy, H. P. (2016). Tratamento de efluentes e recuperação de recursos. Tradução: Ivanildo Hespanhol, José Carlos Mierzwa. (5a ed.): AMGH.

Monteiro, M. M., Baettker, E. C., Aisse, M. M., \& Cubas, S. A. (2019). Avaliação de sistema reator UASB seguido de filtro biológico percolador aplicado na codisposição de lixiviado de aterro sanitário com esgoto doméstico. In: Anais do $30^{\circ}$ Congresso Brasileiro de Engenharia Sanitária e Ambiental: ABES, 2019.

Nocko, L. M. (2008) Remoção de carbono e nitrogênio em reator de leito móvel submetido à aeração intermitente. Dissertação de mestrado. Universidade de São Paulo, São Carlos.

Oliveira, A. C. D. G., Blaich, C. I., Lopes, D. D., Santana, S. V., \& Prates, K. (2013). NMP de bactérias nitrificantes e desnitrificantes e sua relação com os parâmetros físico-químicos em lodo ativado para remoção biológica de nitrogênio de lixiviado de aterro sanitário. Revista DAE, 61, 60-9.

Pereira, A. S., Shitsuka, D. M., Parreira, F. J., \& Shitsuka, R. (2018). Metodologia da Pesquisa Científica. UFSM NTE. https://repositorio.ufsm.br/bitstream/handle/1/15824/Lic_Computacao_Metodologia-Pesquisa-Cientifica.pdf?sequence=1 .

Pereira, E. L., Campos, C. M. M., \& Moterani, F. (2009). Efeitos do pH, acidez e alcalinidade na microbiota de um reator anaeróbio de manta de lodo (UASB) tratando efluentes de suinocultura. Ambiente \& Água-An Interdisciplinary Journal of Applied Science, 4(3), 157-168.

Ruiz, G., Jeison, D., \& Chamy, R. (2003). Nitrification with high nitrite accumulation for the treatment of wastewater with high ammonia concentration. Water research, 37(6), 1371-1377.

Sistema Nacional de Informação sobre Saneamento. Diagnóstico dos serviços de Água e Esgoto: SNIS.

Sousa, J. T., Santos, K. D., Costa, M. J. C., da Costa, P. L. F., \& Mota, M. F. (2005). Avaliação do desempenho do reator uasb na desnitrificação de águas residuárias domésticas. In: Congresso brasileiro de engenharia sanitária e ambiental, 23., Campo grande. Anais: ABES.

Sundberg, C., Tonderski, K., \& Lindgren, P. E. (2007). Potential nitrification and denitrification and the corresponding composition of the bacterial communities in a compact constructed wetland treating landfill leachates. Water Science and Technology, 56(3), 159-166.

Suzuki, L. Y., Batista, A. D., \& Kuroda, E. K. (2013). Estudos ecotoxicológicos de lixiviado de aterro sanitário antes e após várias etapas do tratamento. Periódico Eletrônico Fórum Ambiental da Alta Paulista, 9(11).

Torres, P., Rodríguez, J. A., Barba, L. E., Marmolejo, L. F., \& Pizarro, C. A. (2009). Combined treatment of leachate from sanitary landfill and municipal wastewater by UASB reactors. Water Science and Technology, 60(2), 491-495.

Vadivelu, V. M., Keller, J., \& Yuan, Z. (2007). Effect of free ammonia on the respiration and growth processes of an enriched Nitrobacter culture. Water Research, 41(4), 826-834.

Veronese, C. G., Beal, L. L., Baptista, M. T., \& Girardi, J. P. (2013). Efeito da ausência de oxigênio dissolvido na remoção de DQO e nitrogênio amoniacal em SMBR do tipo Ludkack-Ettinger Modificado (MLE) no tratamento de efluente de refinaria de petróleo. In: Congresso brasileiro de engenharia sanitária e ambiental, 27., Goiânia. Anais: ABES.

Verstraete, W., \& Philips, S. (1998). Nitrification-denitrification processes and technologies in new contexts. In Nitrogen, the Confer-Ns (pp. 717-726). Elsevier.

Wei, D., Xue, X., Yan, L., Sun, M., Zhang, G., Shi, L., \& Du, B. (2014). Effect of influent ammonium concentration on the shift of full nitritation to partial nitrification in a sequencing batch reactor at ambient temperature. Chemical engineering journal, 235, 19-26.

Wu, L. N., Peng, Y. Z., Wang, S. Y., \& Zhang, S. J. (2008). Effect of free ammonia on the short-cut nitrification of the municipal landfill leachate. Huan Jing ke Xue= Huanjing Kexue, 29(12), 3428-3432.

Zoppas, F. M., Bernardes, A. M., \& Meneguzzi, Á. (2016). Parâmetros operacionais na remoção biológica de nitrogênio de águas por nitrificação e desnitrificação simultânea. Engenharia Sanitária e Ambiental, 21(1), 29-42. 